\title{
Foreign Currency Debt, Financial Crises and Economic Growth: A Long Run View
}

\author{
Michael D. Bordo \\ Department of Economics Rutgers University and NBER \\ New Jersey Hall \\ 75 Hamilton Street, \\ New Brunswick, \\ NJ 08901 \\ Christopher M. Meissner* \\ Department of Economics University of California, Davis and NBER \\ One Shields Avenue \\ Davis, CA 95616 \\ David Stuckler \\ Christ Church College, University of Oxford \\ Oxford, OX1 1DP \\ United Kingdom
}

October 19, 2009

\begin{abstract}
:
Foreign currency debt is widely believed to increase risks of financial crisis, especially after being implicated as a cause of the East Asian crisis in the late 1990s. In this paper, we study the effects of foreign currency debt on currency and debt crises and its indirect effects on short-term growth and long-run output effects in both 1880-1913 and 1973-2003 for 45 countries. Greater ratios of foreign currency debt to total debt is associated with increased risks of currency and debt crises, although the strength of the association depends crucially on the size of a country's reserve base and its policy credibility. We found that financial crises, driven by exposure to foreign currency, resulted in significant permanent output losses. We estimate some implications of our findings for the risks posed by currently high levels of foreign currency liabilities in eastern Europe.
\end{abstract}

Keywords: foreign currency debt, currency crises, sudden stops, financial development JEL Codes: F34, F36, F43, N10

\footnotetext{
*Corresponding author: tel: (530) 554-1784; fax: 1 (530) 752-9382; email: cmmeissner@ ucdavis.edu. Acknowledgements: Comments on an early draft from Pedro Elosegui are greatly appreciated as are those from Mark Spiegel, Galina Hale, Jim Lothian, Andy Rose, and participants at the JIMF, Santa Cruz Center for International Economics conference. The usual disclaimer applies.
} 
1 Introduction

Foreign currency liabilities are often perceived as a financial weakness in emerging markets. It is widely believed that these debts exacerbated the severity of the Mexican tequila crisis (1994), Russian ruble crisis (1998) and East Asian crisis in late 1990s (Eichengreen and Hausmann, 1999). As a result, unhedged exposure to debts denominated in foreign currency have substantially diminished. Instead, borrowing governments tend to issue local-currency denominated debt on international markets while lenders increasingly participate in domestic bond markets (Burger and Warnock, 2006 ). ${ }^{1}$ Improved liquidity and depth have expanded the development of local financial markets, and the accumulation of reserves, especially in East Asia, has offered significant insurance against potential future instability.

Nonetheless, foreign currency debt contracts and their potential financial risks have not been eliminated. Exchange rate policy is crucial for managing these debts. Soft pegs, carrying implicit guarantees for exchange rate stability, could lead to complacency and 'excessive' borrowing in foreign currency. Recommendations for reforming exchange rate policy to reduce these risks after the East Asian crisis have focused on two options. First, free-floating exchange rates would help diminish incentives to borrow in foreign currency, and second, monetary unions could eliminate currency mismatches altogether.

Despite progress in implementing these exchange rate reforms in East Asia, some countries have been slower to reform (especially eastern Europe), and the global financial crisis of 2008 has exposed financial weaknesses. Thus far large reserves have helped maintain stability in East Asia. However, the situation facing countries in eastern Europe, particularly the Baltic states, which established pegged exchange rates of intermediate hardness post-1997 and built up significant proportions of private debt and other

\footnotetext{
${ }^{1}$ The GEMLOC project launched in 2008 at the World Bank's IFC aims to track the investibility in domestic local currency denominated asset markets and to support these markets. They report that as of 200870 percent of emerging market debt was denominated in local currency debt.
} 
liabilities payable in euro, dollars and Swiss francs, is widely regarded to be a 'perfect storm'.2

Can financial stability be maintained in these countries despite high proportions of foreign currency debt? Are there other vulnerabilities besides foreign currency debt? Our analysis based on the experience of over 1,700 country years spanning two periods of open international financial integration, 1880 to 1913 and 1973 to 2003, suggests the answers may be affirmative on both accounts. ${ }^{3}$ Despite such conclusions, foreign currency debt, combined with other financial weaknesses remain a vulnerability.

We first investigate the empirical relationship between financial crises and foreign currency debt, economic growth and output. All else equal, we find robust evidence that foreign currency debt increases the likelihood of currency and debt crises. The risks of crisis are the greatest when borrowing in foreign currency is rapid and large, banking systems are prone to crisis, and international reserves are low. ${ }^{4}$ Currency and debt crises lead to significant short term losses in economic growth and to permanent output losses.

We highlight the following additional points:

1) Risk of a crisis can be small even when liabilities are payable in hard currency if financial systems are solid and countries have good reputations in international capital markets. This implies that intermediate pegs can be a viable strategy

2) Minimizing foreign currency financing is not a sufficient condition to eliminate financial crises.

2 Foreign Currency Financing in Two Periods of Globalization: Policy, Observations and Implications

\subsection{Policy and International Financial Architecture with Foreign Currency Debt}

\footnotetext{
${ }^{2}$ Amongst many others see Gros (2009) Gligorov and Landesmann (2009) or Stokes (2009).

${ }^{3}$ Goldstein and Turner (2004) call attention to the mismatch issue. A currency mismatch is measured as the value of foreign currency obligations relative to foreign currency assets and streams of revenues. Financial development and prudent borrowing are other routes to avoiding these costs as we will illustrate.

${ }^{4}$ Other forms of insurance besides reserve accumulation may be less costly and just as effective, but we do not control explicitly for these below.
} 
Close analysis of the East Asian and Latin American crises of the 1990s led Eichengreen and Hausmann (1999) to conclude that external borrowing in foreign currency was a major reason for the severity of these financial crises. In several South East Asian countries and Mexico in 1994 and Argentina in 2001/2002 pegged exchange rates provided an implicit guarantee of exchange rate stability. Households, domestic banks, and non-financial firms built up significant short-term debt denominated in US dollars. Many local banks also borrowed short in dollars and lent long into the domestic economy, expecting payments in local currency,.

Those borrowers involved seemed to dismiss, ignore or discount the possibility that dollar liabilities might increase due to a sharp depreciation. They also appear to have overestimated the capacity or willingness of their governments to maintain fixed exchange rates. Yet repeatedly after 1990 in Mexico, Thailand, South Korea, Indonesia, Malaysia, Russia and Argentina, among many others, governments failed to uphold these pegs against sudden stops to capital inflows. This wreaked havoc on the balance sheets of domestic financial and non-financial firms, leading to successive credit crunches and output losses.

Many policy prescriptions emerged from this era of financial turbulence, with a few key options for mitigating risks associated with foreign currency debt. One option involved enhancing or initiating local currency markets. It was argued that as liquidity rose foreign participation in these markets would increase enabling LDCs to tap surplus country wealth but with local currency debt. Another option was to self-insure through accumulating reserves, an option taken by many of the East Asian counties. However, such policies limited net capital inflows and unsustainable net foreign asset positions.

A related pair of options involved reforming exchange rate policies. A free float would discourage the policy-induced moral hazard thought to be at play in the 1990s (Eichengreen, 2002), and develop markets for domestic debt. There is no doubt that expanding domestic debt markets has alleviated some of the seemingly excess reliance on foreign currency debt. However, having floating exchange rates is a less viable option for most small open developing economies (Calvo and Reinhart, 2002). The second option was for the country to get rid of the exchange rate altogether, instead establishing hard peg currency boards or monetary unions. Unfortunately, abolishing exchange rates is a a 
politically risky strategy. As Argentina's experience showed, when an economy is vulnerable to shocks and lacks the capacity to make necessary quick adjustments, 'ultracredible' currency policies can change suddenly. Thus, forming monetary unions, as in Europe, was the remaining option. So far, relatively few countries in the world have taken the option to 'dollarize' or 'euroize'. The European Monetary Union (EMU) is expanding eastwards but only slowly. Still, there the 2008-09 financial crisis has revitalized interest in joining EMU. Still there are observers who are betting that membership in the EMU may not be permanent, especially for the members with the the largest imbalances or those who face other political challenges (Feldstein, 2009).

\subsection{The Origins of Foreign Currency Debt}

Foreign debt has historically been denominated in only a handful of key currencies like the US dollar, the Japanese yen, the British pound sterling, or the German mark. A high ratio of foreign currency liabilities to total international liabilities was called 'original sin' by Eichengreen and Hausmann because the currency denomination aspect of the contract was ostensibly unrelated to fundamentals. Rich and poor countries, institutionally weak nations, and even countries with strong property rights issue much, or all, of their debt on international markets in foreign currency (Flandreau and Sussman 2005 and Bordo and Meissner 2007a).

As it turns out, domestically issued liabilities have historically carried indexation or foreign currency clauses. The assumption that the international market is the only one of interest is misplaced. Exchange rate indexation clauses in domestic debt can generate distributional consequences when the exchange rate depreciates or inflation rises. These matter whenever capital market imperfections exist, as detailed in long-run evidence of Bordo and Meissner (2006, 2007a). In the rest of our study, we look at total, not just international, debt outstanding whenever possible.

Before 1914, in the first wave of financial globalization, most countries financed themselves with foreign currency debt. Like today, most debt issued in external markets (e.g., London, Paris, and Berlin) was denominated in the currency of the financial 
leaders. Private and sovereign debt contracts often demanded repayment in a fixed weight of precious metal such as gold.

However this was by no means the rule within this period. Many emerging markets managed to place significant amounts of long term debt payable in local currency; and although the 'emerging' countries were commonly regarded as possessing underdeveloped or weak financial systems and dubious institutional foundations they still managed to have significant amounts of domestic currency debt. ${ }^{5}$ Foreign investors were not always shy of holding such debt in their portfolios (Flandreau and Sussman, 2005). These countries included Argentina, Brazil, Chile, Italy, Russia, Spain, Portugal. By contrast, other countries maintained heavy exposure to hard currency debt. These were the countries that would eventually become mature industrialized economies, and which were already leaders in terms of the quality of their institutions, their financial development, their protection of creditors, and the degree of structural change. These markets included the Australasian colonies, Canada, the United States, and Scandinavia. ${ }^{6}$

For this paper we rely on high quality data on the currency denomination of total public debt for 18 countries prior to 1914. These include bonds issued both domestically and externally, and in some respects these data have better coverage than current data which have been used to explore the question. ${ }^{7}$ For the recent past (1973-2003) we rely on data for internationally issued obligations only.

New evidence from the recent decades of financial integration also shows that developing country governments are quite able to market substantial proportions of their total debt in local currency (Burger and Warnock, 2006 and Reinhart and Rogoff, 2008). It appears also that foreign investors may be increasingly willing to hold developing country local currency debt.

These facts and the history of capital flows in the 1990s lead to the following questions: Are countries with the lowest exchange rate exposure guaranteed the most financial stability? Are their other necessary factors which need to accompany a break away from foreign currency debt to ensure financial stability? Can countries manage

\footnotetext{
${ }^{5}$ Reinhart and Rogoff (2008) reach a similar conclusion.

${ }^{6}$ Debt was often denominated in dollars in the United States in the nineteenth century. But nearly all debt (corporate, sovereign, state and municipal) had a gold clause which meant repayment in a fixed quantity of gold was expected.

${ }^{7}$ Reinhart and Rogoff (2008) have also improved the twentieth century data for domestic debt.
} 
foreign currency debt with alternative financial development strategies? Is foreign currency debt imposed by financial markets on the countries that are expected to perform poorly or is such debt generally endemic to most debt issues on global capital markets?

\subsection{Original Sin? A Long Run View Of Hard Currency Debt's Consequences and Origins}

Theoretical models are generally ambiguous about the effect of exchange rate depreciation when foreign currency debt is present. In sticky price macroeconomic models, nominal depreciation in the face of hard currency debt is likely to be contractionary as debt repayments increase. ${ }^{8}$ This traditional view is that the expansionary effect of depreciation on increased exports and decreased imports can offset this impact.

Cespedes, Chang and Velasco (2004) study an open economy IS-LM model with capital market frictions and find that the net impact of a surprise devaluation on income depends on the degree of capital market imperfections, the share of home goods in total consumption, the fraction of total debt denominated in hard currency and the ratio of debt to net worth. Krugman (1999) and Aghion, Bachetta and Banerjee (2000) also derive conditions under which real depreciation can be contractionary.

Jeanne (2000) argues that when foreign currency debt solves a moral hazard problem it may be an efficient solution, but when there is adverse selection it is suboptimal. Caballero and Krishnamurthy (2003) show that when there is financial underdevelopment agents opt for inefficiently high levels of foreign currency debt. The theoretical ambiguity in the predicted effects and rationale for foreign currency debt stands in stark contrast to the policy paradigm developed after 1997 and a general tendency to applaud minimizing foreign currency debt.

What does the empirical work show? Previous work in a long-run comparative vein (e.g., Bordo and Meissner, 2006) finds that foreign currency debt alone does not always generate a higher likelihood of a financial crisis. ${ }^{9}$ Several countries like Canada,

\footnotetext{
${ }^{8}$ Similar outcomes are possible in real models with tradable and not-tradable sectors.

${ }^{9}$ This paper uses information on public debt only.
} 
the US, Australia, and the Scandinavian countries in the nineteenth century, did not have severe financial instability or debt defaults even with significant foreign currency liabilities relative to their total obligations; on the other hand, many countries with low to intermediate ratios of hard currency debt to total debt did have frequent and severe financial crises.

In the late twentieth century, our research documents that many advanced countries exhibited significant amounts of hard currency debt outstanding relative to their total external debt liabilities, but most have avoided being plagued by severe crises. On the other hand, emerging markets which also had a high percentage of their external debt denominated in foreign currency were highly susceptible to debt crises and had high financial instability. Bebczuk, Galindo and Panizza (2006) find that foreign currency debt is directly associated with lower growth rates when the real exchange rate depreciates. Arteta (2003) uses data on currency denomination of deposits and private sector credit and finds that dollarized banking systems are not significantly more prone to crises. Bleakley and Cowan (2008), in a sample of Latin American countries, found no evidence that firms' investment decisions are affected by hard currency debt even in the face of depreciation.

The lesson appears to be that sound debt management at the micro or macro level, financial development, and sustainable fiscal positions have allowed countries to escape financial turmoil even in the presence of a high percentage of debt denominated in foreign currency. Financial development includes many aspects, amongst them are: increasing the attractiveness of holding the domestic currency abroad, deepening liquidity in local financial markets, sound and credible government finances and strong financial intermediation services. Reserve accumulation and strong export capacity can also help avoid the volatility associated with foreign currency debt. Thus, even if countries have not yet developed the foundations of good finances, they can minimize instability by limiting their currency mismatches. This does not imply, however, that only countries with weak finances end up with foreign currency debt, as shown clearly in Eichengreen, Hausmann and Panizza (2005). 
3 International Financial Flows, Hard Currency Debt, Crises and Economic Growth: A Brief Conceptual Framework

Our framework for the empirical analysis is designed to evaluate the associations of foreign currency debt with financial crises and, indirectly, with economic growth. Following the approach of Mishkin (2003) and Jeanne and Zettlemeyer (2005), ${ }^{10}$ our analysis integrates a balance sheet view of the credit channel transmission mechanism with the open-economy. In this framework, balance sheets, net worth and informational asymmetries are key ingredients, as is the development of the financial system.

Based on our review of the literature, the basic framework for an emerging market suggests the following (also see Figure 1):

- Sudden stops or reversals in capital inflows are more likely when the capital account is liberalized or a country receives a surge in capital inflows. The likelihood of a sudden stop is exacerbated by high levels of foreign currency debt relative to total borrowing and low levels of internationally tradable production relative to total output. ${ }^{11}$

- Large capital inflows, sudden stops and current account turnarounds are often subsequently associated with a speculative attack on the currency or sharp currency drops. Currency crises are especially likely when policy makers have low credibility or low reserve positions. If foreign currency exposure is heavy, expectations that debt might not be repaid in the case of a depreciation may lead to a self-fulfilling liquidity crisis and a credit crunch.

- All else equal, foreign currency debt exposure in the face of a sudden and large depreciation of the exchange rate makes private and public debt default more likely. Private agents' balance sheets are impaired. A credit crunch based on widespread insolvencies ensues. The economy sinks deeper into recession and revenues fall giving rise to a further round of

\footnotetext{
${ }^{10}$ Mishkin's informal analysis follows a stream of literature from the late 1990s on the links between net worth, exchange rate depreciation, and crises.

${ }^{11}$ Calvo, Izquierdo and Mejia (2004) and Bordo, Cavallo and Meissner (2008) find direct empirical evidence for this proposition.
} 
disintermediation and so forth. Governments and private agents become more likely to default in such a scenario. Growth is slow until the financial system is repaired and investment recovers.

[Insert Figure 1 here]

\section{Empirical Evidence: The Potential Costs of Hard Currency Debt}

The goal of this section is to provide a rough test of the logic proposed above. These empirical tests then provide a gateway for measuring the impact of hard currency debt on economic growth via its impact on crises. We present evidence that large capital inflows have often contributed to the likelihood of a currency crisis. These sharp and sudden depreciations were also likely to give way to debt crises when foreign currency debt was a significant percentage of the outstanding total and other pre-existing weaknesses were present. A higher propensity to have a crisis depends on these other controls that proxy for financial development and management.

This is the crux of our evidence that hard currency debt alone is not to blame for financial crises. Hard currency debt, combined with good financial development, is associated with a relatively low propensity to experience debt crises in both periods of globalization. Strong financial development limits the probability of a currency crisis and the likelihood of a default in the event of a sharp currency drop.

On the other hand, when other weaknesses in fundamentals are present, even relatively low exposure to foreign currency debt with a sharply depreciating exchange rate is associated with a substantial risk of a crisis. Decreasing dependence on foreign currency debt may not be sufficient to lead to financial stability.

We then focus on the economic costs of hard currency debt. We discuss how original sin and poor financial development together are often indirectly associated with temporarily lower economic growth and negative level effects on income because they hasten financial crises. These factors combined appear to contribute to significantly lower standards of living in countries relying on foreign currency denominated capital inflows to spur development. 


\subsection{The Association between Foreign Capital Inflows and Financial Crises}

The first step in testing the above framework is to see whether foreign capital flows are associated with greater risks of currency crises. We hold constant several factors identified as significant by previous research. ${ }^{12}$ We control for international and year-specific factors using the short term discount rate at the Bank of England (18801913) and later the yield on short-term US treasury bills (1973-2003). We also condition on the lagged level of the ratio of net capital inflows to GDP measured as the (negative) of the change in the ratio of the net international investment position to GDP, the ratio of hard currency government debt outstanding to total government debt (1880 - 1913) or the within country average ratio of foreign currency debt to total debt issued on international markets (this is based on the Eichengreen, Hausmann and Panizza data covering 19731992). ${ }^{13,14}$ Following Eichengreen and colleagues, we call the latter variable original sin. The ratio of gold reserves to monetary notes in circulation (1880-1913) or foreign currency reserves to the money supply (1973-2003), and the presence of a banking crisis in the previous year are also included.

In column 1 and 4 of Table 1, we estimate a probit model where the dependent variable is one if there was a currency crisis and zero otherwise. ${ }^{15}$ Column 1 is for the

\footnotetext{
${ }^{12}$ Previous work (e.g., Bordo and Meissner, 2006) has used other determinants. Many of these are not significantly associated with crises in probit estimations hence we exclude them. All data used in the following exercises are described in the data appendix.

${ }^{13}$ The Eichengreen et. al. average based on data from 1973-1992 is then used for the years beyond 1992 under the assumption that the ratio does not change much over time. The available data for 1972-1992 suggest this variable is very persistent. Comparable data have not been compiled systematically for the 1993-2003 period to the best of our knowledge. Data from the Bondware data series exist but these data do not extend backwards far enough and the coverage of the liabilities is different. Results below appear stable when restricting the sample to 1973-1992 and letting the original sin variable vary by year. Again, this is true because the original sin variable is highly persistent.

${ }^{14}$ The composition of capital flows (portfolio equity or debt or FDI) may matter for crisis probabilities. Ultimately we proceed to growth regressions with all capital inflows which what much of the literature on growth and capital flows in the last five years has analyzed.

${ }^{15}$ Currency crises are defined using an exchange market pressure index as in Bordo et. al. See the appendix for details.
} 
period 1880-1913 and covers the experience of 18 countries listed below Table 1 while column 4 covers 45 listed countries between 1973 and 2003. Columns 1 and 4 of Table 1 show that a large inflow of capital relative to GDP has a positive association with currency crises - this marginal effect is statistically significant at the 95 percent level pre1913 and the 90 percent level post-1973. The coefficient on the 'original sin' variable is not statistically significant in the first period, but it is positive and statistically significant in the second period. Higher interest rates in the financial centers are associated with a higher chance of a currency crisis. Lower levels of reserves predict higher probabilities of a currency crash in both periods, but this result is only statistically significant in the first period. Finally, between 1973 and 2003 there is some evidence that a banking crisis in the previous year is associated with crises in the current year.

[Insert Table 1 here]

\subsection{Debt Crises and Hard Currency Debt}

The next link in our framework in Figure 1 relates currency depreciation, liability "dollarization" and the other fundamentals to debt default. Results from a pair of probit models are shown (column 2 and column 5 in Table 1) which use an indicator for the first year in which a country defaulted (partially or in whole) on its sovereign debt obligations as a dependent variable. Here we also find evidence consistent with our framework.

First we see that the marginal impact of a higher ratio of hard currency debt to total debt outstanding, without a currency crash, is associated with a higher probability of having a debt crisis only after 1972 (Columns 2 and 5 of Table 1). In both periods, having a currency crisis amplifies the positive association between hard currency debt and a debt default. We illustrate the impact on predicted probabilities below in Table 2 . The interpretation is that real depreciation increases the real burden of foreign currency debt making default more likely.

[Insert Table 2 here]

The following conclusions can be made based on these regressions: foreign currency debt is likely to be associated with debt crises after large foreign capital inflows. 
Such inflows would be associated with significantly increased external debt burdens, and these are seen in column 1 and 4 to heighten the possibility of a currency crisis. The interaction in columns 2 and 5 of Table 1 of the hard currency debt ratio and the currency crisis indicator shows these inflows limit the "sustainability" of a high ratio of hard currency debt outstanding to total debt.

In terms of proxies for financial development, we have several findings. First, a banking crisis in the previous year is a positive and statistically significant determinant of debt crises. ${ }^{16}$ Low reserves relative to the money stock are also related to a higher likelihood of having a debt crisis, but in neither period is this coefficient statistically significant. ${ }^{17}$ We find strong support that original sin and balance sheets matter, but we also find evidence that strong financial systems are important for explaining the (lack of) incidence of major financial meltdowns.

4.3 Interactions between Fundamentals and Hard Currency Debt on the Likelihood of a Debt Crisis

In Table 2 we illustrate the impact of hard currency debt ratios on predicted probabilities of debt crises. We also probe into the interactions between hard currency debt and other fundamentals. Table 2 presents predicted probabilities of a crisis using the estimated coefficients from the models of Table 1, a 100 percent hard currency debt ratio and a range of values for the other included covariates which are associated with financial development and financial robustness. These results indicate that the fragility induced by hard currency debt can be overcome to some extent with better fundamentals.

We define the following fundamental conditions: "excellent fundamentals" as an observation with the sample average reserve to money stock ratio, no banking crisis in the previous year, and no currency crisis this year; "good fundamentals" as a country that has "excellent fundamentals" but falls victim to a currency crisis; "bad fundamentals" has a banking crisis in the previous year and no international reserves; and finally the "worst

\footnotetext{
${ }^{16}$ Banking crises could also be endogenous to financial turmoil as balance sheets implode. Such fragility however suggests weak regulatory regimes or vulnerabilities in the first place.

${ }^{17}$ Currency crises are associated with a lower likelihood of a debt crisis in the second period until the ratio of hard currency liabilities is sufficiently high.
} 
fundamentals" situation occurs with no reserves and a twin banking and currency crisis. Across all scenarios we set the level of net capital inflows and the short-term interest rate at the sample mean.

The following conclusions are evident from Table 2:

1) Scenario 1 "Excellent fundamentals" shows that a 100 percent hard currency debt to total debt ratio is associated with a small likelihood of a debt crisis in both periods.

2) Scenarios 2 and 4, which allow for currency crises, demonstrate that depreciation with hard currency liabilities significantly raises the predicted likelihood of having a debt crisis above that of scenario 1. This is the case both for countries with good fundamentals and bad fundamentals. The predicted probability of a debt crisis in the recent period is 0.18 or 0.63 in the earlier period with the "worst fundamentals". Having strong reserves and no banking crisis reduces these probabilities by $2 / 3$ as seen in Scenario 2 .

3) Scenario 3 shows that avoiding currency crises is crucial. Even with weak fundamentals and $100 \%$ of debt denominated in foreign currency, the predicted probability of a debt crisis is roughly 0.08 post 1972.

3) A 100 percent ratio of hard currency debt relative to total debt (or international debt post-1972), combined with a move from the best to the worst fundamentals (a move from scenario 1 to scenario 4), raises the predicted probability of suffering a debt crisis by over 70 times in the first period and nearly six fold in the second period.

\subsection{Robustness of Crisis Determinants}

In this section, we test whether our crisis models are robust to several potential data limitations and alternative explanations, including possible endogeneity of the 
foreign currency debt variable (e.g., worst countries borrow more in foreign currency) and the robustness to the sample (i.e., the G-7 could be driving the positive relationship between crises and foreign currency debt).

In terms of endogeneity, the proportion of foreign currency debt could depend on unobservable factors that are associated with risks of crisis. One possibility is that choosing to borrow in foreign currency is positively related to other factors which heighten the likelihood of crises, such as moral hazard. If moral hazard is a key issue, then creditors may demand that countries borrow in hard currency so as not to inflate away' their debt. Reinhart, Rogoff and Savastano (2003) argued that original sin was a symptom of deeper flaws in the ability to repay debt. On the other hand, as discussed above, the origins of foreign currency debt also seem to involve market issues such as liquidity. Small countries in Scandinavia, and even the US until 1933, suffered from original sin while in Tsarist Russia, a country not known for its international reputation for solid monetary affairs, had a significant amount of rouble debt held in London (Flandreau and Sussman 2005).

We attempt to control for potential endogeneity using the size of an economy, measured as the logarithm of GDP, as an excluded instrumental variable. Economic size is mostly related to geography, geopolitics and military factors over the centuries, and it is likely to be uncorrelated with current unobservables such as debt sustainability or exchange rate peg credibility. Still, size is correlated with original sin. Eichenegreen, Hausmann and Panizza (2006) observed that size was about the only thing that could explain variations in original sin during the recent period. This observation seems to fit the facts with Russia in the nineteenth century as well (Flandreau and Sussman, 2005).

Table 3 reports results from one-step maximum likelihood instrumental variable probit regressions, parallel to those in Table $1 .{ }^{18}$ The results for both the currency and debt crisis specifications in the first wave suggest no statistically significant relationship with crises. However, a Wald test for the first wave of globalization suggests we cannot rule out the exogeneity of the foreign currency debt ratio in either specification. This is

\footnotetext{
${ }^{18} \mathrm{We}$ are unable to include an interaction between original sin and currency crises in the debt crises models. Using the interaction of a currency crisis and the hard currency debt ratio made estimation unfeasible. Still since the probit models carry a non-linearity in their marginal effects one can see evidence of interaction between original sin and depreciation.
} 
not wholly at odds with the historical empirical observations about the origins of original $\sin$.

\section{[Insert Table 3 here]}

In the second period, the coefficient on original sin in the currency crisis model is positive, small but not statistically significant. This suggests that our finding of a positive statistically significant coefficient in Table 1 was due to endogeneity. On the other hand, in the probit model for debt crises, we find a positive and statistically significant coefficient. It was not feasible to test directly for an interaction between currency crises and original sin in the debt crisis model as in Table 1. However, the coefficient on the control for a currency crisis is large, positive and statistically significant, so the marginal impact of the original sin variable would become stronger in the face of a currency crisis. ${ }^{19}$ In both specifications post-1972, we reject the exogeneity of the original sin variable. Our bottom line is that endogeneity may be a cause for concern in currency crises since expected currency depreciation may naturally lead to hesitancy of creditors to lend in local currency. Still, once we control for these factors in the debt crisis model with a currency crisis indicator, it appears that original sin can heighten the probability itself of a debt crisis.

We also test robustness to the sample. ${ }^{20}$ In Table 4 we drop G7 countries plus Switzerland. This leaves plenty of advanced but small countries with high levels of original sin but drops almost the universe of countries in the world that have the lowest levels or original sin. ${ }^{21}$ This results in a lack of variance in the original sin variable, and it is perhaps one reason that column 1 (currency crises) and column 2 (debt crises) show no statistically significant relationship between such crises and original sin. Once we instrument for original sin as before, we find an unintuitive negative and statistically

\footnotetext{
${ }^{19}$ This is due to the non-linearity of the probit model.

${ }^{20}$ Prior to the late 1980 s private capital flows to many emerging markets were low and mainly from official sources. Unreported probits for a sample that begins in 1988 finds qualitatively similar results to those reported in Table 1.

${ }^{21}$ The data show that only nine countries are below 90 percent and above 47 percent (Portugal, Australia, Spain, New Zealand, Netherlands, South Africa, Hong Kong, Denmark, Belgium). Austria is the next lowest at 90 percent followed by 11 countries with ratios of 93 to 99.7 . The next 16 countries have 100 percent ratios.
} 
significant coefficient on original sin for currency crises and a positive statistically significant coefficient on original sin for debt crises. In the latter case, we cannot reject the exogeneity of original sin. Our bottom line here is that plenty of advanced countries 'suffer' from original sin but they manage to avoid crises that are related to variables for which we do not or cannot control. Weaker or 'less credible' countries have difficulty carrying such debt.

[Insert Table 4 here]

\section{Economic Growth, Output and International Capital Flows}

\subsection{Foreign Currency Debt, Financial Crises, and Economic Growth}

We have now established that a high proportion of debt in foreign currency can under certain circumstances be associated with a greater risk of financial crisis. In this section, we examine whether such forms of debt have an impact on per capita output via financial crises. This chain of logic will allow for a measure of the growth and output losses implied by foreign currency liabilities via their impact on crises.

We follow closely Bordo and Meissner (2007b) who investigate the relation between financial flows and growth and Loayza and Ranciere (2005) who investigate financial liberalization and growth in the short and long-run. ${ }^{22}$ Specifically we first present a series of cross-country growth regressions for five-year periods which include as key explanatory variables net capital inflows and episodes of financial crisis. By including financial crises we can recursively track the impact on growth of hard currency debt via the crisis variable. Our second set of results uses annual data to look at long and short-run impacts on output of capital flows and financial crises.

5.2 Multivariate Growth Regressions: Tracking the Growth costs of Liability Dollarization

\footnotetext{
${ }^{22}$ Ranciere, Tornell and Westerman (2006) also examine the short and long run impacts of financial liberalization
} 
We explore growth in real per capita GDP in non-overlapping five year periods for the sample 1880-1913 and then for the 1973-2003 sample. Between 1880 and 1913 we use a set of twelve countries for which we have savings data and then a set 19 countries (the same twelve as before plus seven other countries) when we drop the savings variable from our regressions. ${ }^{23}$ For the period 1973-2003 we look at the experience of 49 countries.

Our key control variables are the level of net capital inflows/GDP and the average number of years that witnessed a financial crisis during the five year period. ${ }^{24}$ Based on evidence from our probit models above, hard currency debt--the focus of this study-is a key determinant of crises. If so, then such variables may have an indirect effect on growth.

To capture the direct impact of global capital market integration, we used the average of the ratio of the net capital inflows to GDP in the five year period. Of course, in an open economy, investment is the sum of two components: net foreign borrowing and net national saving. Hence we also include the five year average of the ratio of domestic savings to GDP. ${ }^{25}$

The other explanatory variables are standard and based on Mankiw, Romer and Weil (1992) and later papers that study economic growth empirically. We include the following controls in Table 5: the logarithm of GDP per capita in the initial year of the five year period, the five year average of the population growth rate, the five year average of the percentage of the population enrolled in primary school, and the level of exports divided by GDP or imports plus exports divided by GDP in the latter period.

\footnotetext{
${ }^{23}$ The set of twelve countries includes: Argentina, Australia, Canada, Denmark, France, Germany, Italy, Japan, Norway, Spain, Sweden, United States. The sample of 19 adds in Austria, Brazil, Egypt, India, New Zealand, Portugal, Uruguay.

${ }^{24} \mathrm{We}$ take the sum of indicators for the first years of a currency, debt or banking crises during a five year period and average this value within the five-year period. Multiple types of crises in one year are counted as one event.

${ }^{25}$ Where we do include savings, we do not adjust the savings variable downward for countries with capital outflows because the main capital suppliers are already excluded form the data set. Also the current account data are not directly comparable with the Stone data which would make a proper adjustment difficult. Data on saving are from Taylor (2002) who calculated the ratio of saving to GDP as the current account surplus divided by GDP plus the ratio of investment to GDP. We also used the investment ratio instead of borrowing and domestic saving and found that the investment ratio was not statistically significant in the growth regressions.
} 
Regressions are of the form

$$
\begin{aligned}
& \text { Growth }_{i t}=\alpha_{0}+\alpha_{1}\left(\frac{\text { ForeignK }}{G D P}\right)_{i t}+\alpha_{2} \text { crisis }_{i t}+\alpha_{3}\left(\frac{\text { Saving }}{G D P}\right)_{i t}+\alpha_{4}\left(\text { Enrol }_{i t}\right)+ \\
& \alpha_{5}\left(\frac{\text { Exports }}{G D P}\right)_{i t}+\alpha_{6}(\Delta \ln (\text { Population }))_{i t}+\alpha_{7} \ln \left(\frac{G D P}{\text { population }}\right)_{i 0}+\mu_{i}+\delta_{t}+\varepsilon_{i t},
\end{aligned}
$$

where all variables are averaged over non-overlapping five year periods themselves indexed by $t$, Growth is the average annual growth of real per capita output, $\Delta$ $\ln$ (population) represents the (five-year average) of the annual log differences in population levels, the 0 subscript on GDP per capita stands for the initial year of the five year period, $\mu_{i}$ is a set of country "fixed effects," $\delta$ is a vector of quinquennial period indicators, and $\varepsilon$ is an idiosyncratic error term for each country within each five year period. $^{26}$

[Insert Table 5 here]

In columns I to IV of Table 5, we present results from regressions of the growth equation above for 1880-1913 and 1973-2003. Columns I and III leave out national saving which slightly expands the sample in the first wave of globalization.

The results on the standard growth controls (especially initial GDP and schooling) are in line with expectations from the rest of the empirical growth literature. Domestic saving is positive and statistically significant only in the second period. School enrolment and trade exposure are positively related to growth in both periods. Initial GDP has a negative coefficient and it is statistically significant implying conditional convergence; population growth rates are not statistically significant.

Turning to our results on capital flows, we find no evidence of any association between international capital inflows and economic growth. The coefficient on net capital inflows is never statistically significant. It does appear that the inflows variable is negatively correlated with savings since when savings is omitted the point estimate of

\footnotetext{
${ }^{26}$ We correct the standard errors for heteroscedasticity by using robust standard errors. We also cluster these at the country level.
} 
this variable is negative. When savings is included, the point estimate on inflows becomes positive.

The weight of the evidence from Table 5 is that periods plagued by crises are bad for growth within the five year periods in which they occur. The point estimate of the coefficient for the average number of years in the five year period spent in crisis suggests average growth falls by one to two percentage points during crises. The average annual growth rate is 1.73 suggesting a loss of at least a full year's growth for one year crisis events. Crises represent significant temporary negative shocks to growth which are likely to have a long-run negative level effect on income per capita. ${ }^{27}$

\subsection{Long and Short-run Output Effects of Capital Flows and Crises}

The preceding specifications did not look at whether crises have a permanent or transitory impact on output per capita. Our results suggest that crises leave economies at lower levels of output in each and every year after a crises, but Calvo, Izquierdo and Talvi (2006) argued that economies suffering sudden stops and crises recovered quickly making phoenix comebacks. This was evinced by showing nations reached pre-crisis output levels within 2 or three years of an event which ignores that, absent a crisis, output would have been even higher. Also Loayza and Ranciere (2005) and Ranciere and Tornell (2009) analyze empirically and theoretically (respectively) short and long-run impacts of financial liberalization and economic growth. ${ }^{28}$ Liberalization often yields more volatile growth but also offers faster growth than staying closed. We investigate whether financial flows in both periods of globalization have permanent or short-run impacts on the level of output per capita and whether crises have a similar impact.

Specifically Table 6 implements an $\operatorname{ARDL}(p, q)$ fixed effects panel regression in error correction form. We look at both short-run changes in output per capita and longrun determinants of output per capita so our model is in error correction form. Our estimating equation is$$
\Delta y_{i t}=\sum^{p-1} \psi_{j} \Delta y_{i t-j}+\sum^{q-1} \delta_{j} \Delta X_{i t-j}+\varphi\left[y_{i t-1}-\left(\beta X_{i t-1}\right)\right]+\varepsilon_{i t} .
$$

${ }^{27}$ Further unreported growth reggtessions show fkrat lagged crisis indicators are not associated with aboveaverage growth rates. There is little evidence of phoenix miracle recovery.

${ }^{28}$ In Ranciere and Tornell, and Westermann (2008) countries with more negative skewness of credit growth (i.e., more crises) grow faster on average. We do assess this hypothesis in this paper.
} 
The dependent variable in equation (2) is the annual change (denoted by $\Delta$ ) in the logarithm of GDP per capita $(y)$. Short-run or transitory associations are analyzed by using annual changes in the explanatory variables $(X)$ used in Table 5. Lags in these changes yield an indication of the medium run impact of such variables. We also include one lag of growth. Long-run relationships between output per capita are isolated in the error correction term in square brackets by including lagged levels of the explanatory variables and the level of the dependent variable (i.e., the lagged level of GDP per capita). The error term is a composite error term consisting of year dummies, country fixed effects and country-time idiosyncratic errors.

The methods we use in this section are discussed theoretically in Pesaran and Smith (1995). ${ }^{29}$ Our specification is comparable to that of Loayza and Ranciere (2005) who investigated the short and long-run impacts of financial development on growth. However, we did not find it feasible to allow for country specific short-run coefficients, so we assume slope homogeneity throughout. A benefit of the ARDL approach is that inclusion of sufficient lags of the variables of interest can mitigate endogeneity problems. We include one lag of the growth rate of GDP per capita, contemporaneous changes, and up to a second lag, in capital flows and for the crisis indicator up to two lags and the contemporaneous change. For other variables we only include the contemporaneous annual changes to conserve on degrees of freedom. Our results appear robust to alternative lag structures on the crisis and capital flows variables.

Table 6 shows our results for both periods. First, surges in capital inflows seem to raise output in the short term. In the first wave of globalization, permanent changes to

\footnotetext{
29 If there is a unique vector defining the long-run relationship between the variables and the lag orders are appropriately chosen, then the auto-regressive distributed lag model provides consistent estimates of the parameters, regardless if the variables are stationary only after first differencing. The 'Nickell bias' arises when the lagged dependent variable and the error term are correlated due to the inclusion of country fixed effects. The bias diminishes as the length of the panel increases. In our case, since we have over thirty years of observations, the bias is minimal. Other specifications such as the pooled mean group estimator and the mean group estimator would allow for heterogeneous dynamics. These specifications were infeasible so we report only the pooled dynamic fixed effects estimator which may contain bias is the adjustment coefficient vary by country.
} 
capital inflows seem to raise output. In the second period, even after controlling for crises, they seem to be associated with slightly lower levels of output per capita.

[Insert Table 6 here]

For both samples, crises bring output down but in different ways. In the first wave, crises seem to have a permanent negative effect on output. In the latter period the onset of crises brings output down while recovery would be associated with a rise. ${ }^{30}$ This is consistent with a phoenix type recovery. However, such catching up is not sustained long enough to fully recover to where the pre-existing trend would have taken a country in terms of levels. The evidence in the second period is that crises are associated with long-term loss in output equivalent to the original fall or on average $1.5 \%$. In the first wave of globalization the permanent output losses are larger at about $4 \%$.

The point estimates on the other long-run coefficients roughly support the predictions of a human capital augmented neoclassical growth model. Overall, these models suggest, as before, that crises bring growth down in the short term and also lead to long-term output losses. Capital flows increase growth in the short-run but in the second period run they seem to be bring permanent output losses. We are somewhat sceptical of the latter finding. Perhaps this is evidence of the fact that relatively poor countries receive the largest capital inflows. But even here, this is at odds with findings from the recent period that capital has been flowing 'uphill'. In any case, the connection between crises and growth and output losses comes out clearly in both periods of globalization. We now look at the impact of hard currency debt on overall economic performance via financial crises.

\subsection{The Quantitative Impact of Foreign Currency Debt on Growth}

The combined evidence from Tables 1 through 4 suggests that foreign currency debt, by triggering financial crises, could be responsible for significant temporary reductions in economic growth and permanent output losses arising from those crisis events. How much of a role does foreign currency debt play in all of this? We first look at

\footnotetext{
${ }^{30}$ The change in the crisis indicator would be 1 in the first year of a crisis and -1 in the year after the crisis ends.
} 
the predicted probabilities of having a debt crisis at various values of fundamentals. We focus on debt crises since evidence is strongest here for the connection between such debt and crisis.

In Table 2 we exhibit the predicted probabilities of debt crises based on the probit models of Table 1 columns 2 and 5. A country with "excellent fundamentals" would not have a crisis with predicted probability of 0.98 but would have a debt crisis with a predicted two percent chance. ${ }^{31}$ Now look at the predicted values of growth, as a function of predicted crisis probabilities and using the following equation from our first set of growth regressions. One can write

$$
\begin{aligned}
& E(\text { Growth } \mid X)=\hat{\alpha} X+\hat{\alpha}_{2} E(\text { crisis })=\hat{\alpha} X+\hat{\alpha}_{2}\left\{1 \cdot \Phi\left(\hat{\beta}_{z}\right)+0 \cdot\left(1-\Phi\left(\hat{\beta}_{z}\right)\right)\right\}= \\
& \hat{\alpha} X+\hat{\alpha}_{2} \Phi\left(\hat{\beta}_{z}\right),
\end{aligned}
$$

where $\Phi($.$) is the cumulative distribution function of the standard normal used in the$ probit model (i.e., the predicted probability of having a debt crisis at given levels of the covariates $z$ and estimated coefficients) and the variables in $X$ are the controls used in the growth regressions besides the crisis variable.

Suppose a country has "excellent fundamentals" (n.b., this kind of country has 100 percent hard currency debt). Using the estimated coefficient on the crisis variable, $\hat{\alpha}_{2}$, from column IV of Table 5 (i.e., the 1973-2003 period), and the predicted probability of a crisis from column 2 of Table 2, the contribution to the predicted growth rate from a crisis is a decline of 0.03 percentage points $(-0.03=-1.37 * .02)$. In this case, hard currency debt hardly seems injurious. ${ }^{32}$

Next we look at how hard currency debt interacts with other control variables to form a volatile combination of fundamentals and low growth. A high ratio of hard currency debt to total debt, combined with poor fundamentals, is in fact associated with significantly lower growth.

\footnotetext{
${ }^{31}$ This assumes one crisis per five year period that lasts one year. The effects will be larger if crises last longer or crises are serially correlated as the raw data suggest.

${ }^{32}$ Other covariates in the probit are defined at the sample means.
} 
Consider a country with the "worst fundamentals." In the first and second periods respectively, our models predict a loss in growth of just over two percentage points (-1.78 $=-2.84 * 0.63)$ and 0.28 percentage points $(-0.28=-1.37 * 0.21)$. Both of these impacts are economically significant given mean growth rates of per capita income are 1.33 and 1.7 in the respective time periods.

Consider also a thought experiment that raises hard currency debt from 50 percent of the total to 100 percent of the total. Let fundamentals be the "worst" (i.e., hold reserves at zero, with the country experiencing a currency crisis this year and a banking crisis in the previous year). Next calculate the predicted probabilities of a debt crisis under these two debt ratios using the probit model of column $\mathrm{V}$ of Table 1. Finally use the coefficients on the crisis variable in the growth regressions of columns II and IV in Table 5.

In the case of this doubling of hard currency debt, we find the growth rate would drop by 0.91 percentage points in the first period and 0.28 percentage points in the second period. ${ }^{33} \mathrm{~A}$ doubling of the reliance on hard currency debt when accompanied by weak fundamentals is associated with significant losses in economic growth although the impact is stronger in the first period of globalization.

Another way of looking at this result is available. Between 1973 and 2003 a halving of the hard currency debt ratio, assuming "worst fundamentals", could eliminate much of the reduction to expected growth we found above and which we attributed to hard currency debt. On the other hand, in the first wave of globalization, we find that such a reduction in the hard currency debt ratio only eliminates half of the lower expected growth that arises from 100 percent hard currency debt. Even though the expected negative growth impact is lower in the second period, hard currency debt plays a much stronger role in accounting for the poor growth performance associated with crises in the second wave of globalization.

Another thought experiment is to look at the long-run level effects implied by the results in Table 6. Here crises are associated with a long-run decline in the level of output

\footnotetext{
${ }^{33}$ To arrive at this number, subtract the predicted probability of crisis with a 50 percent ratio of hard currency debt $(0.31$ or 0$)$ from that when there is a 100 percent hard currency ratio $(0.63$ or 0.21$)$. Then multiply this difference by the crisis coefficient in the growth regression (i.e. -2.84 or -1.37 ).
} 
per capita of 1.5 percent in the second period and 4 percent in the first period. ${ }^{34}$ Suppose that a crisis event was a once in a lifetime event and that a country had the worst fundamentals. The expected present discounted value of the income losses, with a constant discount factor of 0.95 and assuming a loss of $\$ 75$ of income per year postcrisis (roughly 4 percent and 1.5 percent less than the average income per capita in each respective sample) would be roughly $\$ 945$ (i.e., $945=[0.63 * 75] \div .05)$ in the first wave and $\$ 315$ (i.e., $315=[.21 * 75] \div .05$ ) in the second wave. As Ranciere and Tornell (2009) show, more information about the exact costs of crises and the level of completeness of financial markets would need to be known to make a more explicit welfare calculation, but these costs do not seem totally trivial. Moreover, many countries face an ongoing threat of crisis in subsequent years so that these costs can be compounded. The sample average for frequency of crises in Bordo and Meissner (2006) is 6 and 14 percent respectively. These imply crises every 16 or 7 years. The average person living 70 years in an economy exposed to such frequencies would see between 5 and 10 crises per lifetime. From an ex ante perspective, the costs indicated above could be increased significantly due to the fact that crises are recurring events in many emerging market economies.

Our results from the second period generate a strong non-linearity in the debt crisis model (but not in the currency crisis model). With the worst fundamentals and a 50 percent hard currency debt ratio, the predicted probability of a debt crisis is nearly zero. The predicted probabilities of a debt crisis do not rise above 0 until hard currency debt ratios rise above 90 percent. This is due to the fact that most countries have in fact had in the past 100 percent ratios of hard currency debt to total international debt and currency crisis before defaulting.

We turn now to an out of sample forecast for Eastern Europe. The non-linearity above turns out to be somewhat crucial in understanding why our models predict that countries in Eastern Europe (in our subsample) should be relatively safe from a debt default associated with their foreign currency debt exposure. However, currency crises

\footnotetext{
${ }^{34}$ Unreported regressions show that contrary to the theoretical argument in Ranciere and Tornell (2009) there is no evidence of higher growth rates associated with permanent rises in foreign financing.
} 
may be a problem and other systemic features of the international financial landscape may yet lead to a debt crisis outcome.

6 Eastern Europe and the Global Credit Storm of 2008-2009.

The outbreak of the global credit crunch in 2008 has put many countries in Eastern European on the radar screen of global capital market analysts looking for the next financial crisis. Significant and persistent current account deficits since 1998 seen in Figure 2 are seen as one potential weakness. Commentators have also pointed out that national balance sheets are increasingly composed of foreign currency obligations. Households in Hungary are reported to have favored mortgages in Swiss francs due to the lower interest rates and overall foreign currency exposure of private borrowing may be up to 70 or 80 percent of all liabilities in Estonia and Latvia.

\section{[Insert Figure 2 here]}

Optimists who would demonstrate that Eastern Europe is not likely to become the latest episode in the current global meltdown cite the fact that overall exposure by developing country creditors to Eastern Europe is relatively small as a percentage of source countries' GDP. For this reason one potential channel for contagion or a selffulfilling blowout may be restricted since maximum losses should be relatively small. Sovereign debt is also not deemed to be excessive, and some countries as of 2008 have floating exchange rates (e.g., Poland, Czech Republic and Hungary) which has dampened the build up of foreign currency liabilities as their currencies have slid and wobbled in the past two years. Slovakia has also just joined the Euro and so its currency mismatches may be more limited. Still, particular countries are on the shortlist for the next financial crisis headline due to their exchange rate policies and external debt positions. The Baltic nations and Bulgaria have intermediate to hard pegs for instance and significant foreign currency liabilities. Specific financial institutions based in Austria and Italy are cited as precariously exposed to Eastern Europe. This makes for the potential that eastern troubles inflict damage on western European economies as these losses get mopped up by domestic authorities via bailouts. 
6.1 Out of Sample Forecast: Is Foreign Currency Debt a Problem for Growth in the East?

Using recent data for 2008 and our models from Tables 1 and 5, we attempt to gauge the risk of debt and currency crises in several Eastern European nations and the expected growth impact of such a crisis. Table 7 lists the values of explanatory variables inserted into the probit models of Table 1 for several Eastern European countries (Czech Republic, Slovakia, Poland, Romania, Bulgaria, Lithuania, Hungary, Estonia and Latvia), the predicted probability of a debt default and a currency crisis, the average growth rate of per capita GDP from 2003 to 2008, the expected reduction in growth in percentage points (equal to the growth losses of 1.37 percentage points from Table 5 multiplied by the predicted probability of having a debt crisis), and the expected loss relative to average growth between 2003-2008 in percentage terms.

Table 7 shows the forecast risks of debt crises are low and for currency crises the risks are moderate to low. In this way, expected growth should be near trend. What accounts for this rosy scenario?

\section{[Insert Table 7 here]}

Since no country is reported to have above a 90 percent ratio of hard currency debt to total debt, predicted probabilities of debt crises are near zero. Currency crises are predicted to be somewhat likely in the following countries: Bulgaria (0.04), Lithuania (0.04), Hungary (0.04), Estonia (0.07) and Latvia (0.09). ${ }^{35}$ To the benefit of many of these countries, international interest rates are also much lower than their long-run average and reserve positions are fairly strong.

Table 7 shows Estonia and Latvia are most at risk of a currency crisis and are consequently forecast to lose the most in terms of economic growth due to such a crisis. ${ }^{36}$

\footnotetext{
${ }^{35}$ The ratio of foreign currency debt to GDP is roughly 70 percent in Latvia and Estonia (Rosenberg, 2008). This could be cause for alarm as well. Also our earlier measure's denominator was international liabilities. No evidence on the proportion of total foreign liabilities denominated in foreign currency was readily available. This is the measure used in the probit models of Table 1. If we assume that all foreign debts were denominated in foreign currency predicted probabilities would be: 0.13 (Czech Republic), 0.11 (Slovakia), 0.12 (Poland), 0.18 (Romania), 0.2 (Bulgaria), 0.14 (Lithuania), 0.11(Hungary), .01(Estonia), 0.29 (Latvia).

${ }^{36}$ The Baltics seem intent on maintaining their pegs. Latvia has entered into an IMF program as of early 2009 but has not been forced to devalue. Lithuania still is aiming to join the European Monetary Union in 2010 .
} 
These countries have the highest levels of foreign currency financing, have built up large negative international investment positions and have quasi-currency board systems that may not withstand the pressures of adjustment. Still, in expectation, growth rates should be down by less than 2 percent (not percentage points).

The largest countries in this subsample, the Czech Republic, Slovakia and Poland have low ratios of foreign currency debt to the total (c. 12-14\%) and overall net external indebtedness is fairly low. All of these countries are also floating their currencies which may help speed the adjustment process. Indeed, Poland's central bank was able to cut interest rates during the global crisis. Contrast this with the Baltic states where interest rates jumped upwards and liquidity disappeared. Floats may also have limited the amount of build-up of large foreign currency liabilities unlike in the Baltic countries where pegs have been the long-standing policy. It would appear that some of the larger countries examined here have learnt from the past by limiting currency mismatches and floating their exchange rates sufficiently to obviate moral hazard. Moreover, ECB and Federal Reserve monetary policies have been extremely loose which is contrary to previous events when center country interest rates in the 1980s and in the 1990s exacerbated financial stringency.

Still, if the recent past has taught us anything, fundamentals are not the only factor in generating crises. Contagious spillovers and sudden stops of inflows, perhaps arising from margin calls on already weakened western European banks, are not fully accounted for in these models. Hence the likelihood of a crisis may be somewhat higher than is reflected in our calculations and further turmoil could be possible. ${ }^{37}$

\section{Conclusions and Comparisons over Two Periods of Financial Globalization: Implications for International Financial Architecture}

\footnotetext{
${ }^{37}$ As of 31July, 2009 Latvia, Hungary and Romania had turned to the IMF for financial support. Hungary however managed to place 1 billion euro in bonds after their original demand of 500 million was oversubscribed. It would appear that a credible commitment by the ECB and the fiscal authorities within the Eurozone has managed to help stabilize expectations in this region. Few emerging markets in the past have had such support in the midst of a systemic crisis.
} 
We have compared long-run associations of foreign currency debt with financial crises and economic growth in two periods, 1880-1913 and 1973-2003. We found strong evidence that both hard currency debts and capital inflows are associated with crises that lower growth temporarily and permanently reduce output compared to the long-run trend.

The remedies and lessons from the East Asian and Latin American crises in the 1990s have been either to reinforce domestic debt markets and reserves and to float or choose a hard peg and cope with hard currency debt. Both options would diminish the currency mismatch. Globally, net foreign currency exposure has not been totally eliminated since 1997, but it appears to be declining. Indeed, the data show, and our model supports the idea that several eastern European countries have done much to mitigate the potential risks of crisis by limiting exposure to foreign currency debt. Still, the Baltic nations have not been so fortunate and have found the adjustment process extremely contractionary. International conditions and political forces may still result in a sudden stop, causing currencies to depreciate and a high risk of default.

Our analysis also shows that hard currency debt is only a partial explanation of the risks of financial crisis. Countries in our sample have demonstrably been able to complement foreign currency debt with stronger financial development and a large reserve base to mitigate risks of major financial crises. The US, Australia, Canada and the Scandinavian countries had significant currency mismatches throughout the nineteenth century but avoided major economic disasters. Today a large set of small but developed countries (Iceland perhaps being an exception due in part to its lax financial regulation) appear to have done the same.

Finally, although countries have now started to minimize currency mismatches, uneven development, mis-guided and unregulated credit booms, sudden stops and contagion continue to pose threats of crisis. In other words, reducing reliance on foreign currency debt has been one, albeit small, step towards improving international financial stability. However, remaining issues from the debate on international financial architecture include: establishing an international lender of last resort, balanced liberalizations in environments of best-practice financial regulation, sovereign debt restructuring mechanisms, and implementing standard accounting principles to increase transparency. 
Thus far, the credit crunch of 2008 and the ensuing financial turmoil have mainly affected high-income countries, but there are prospects for further turbulence in the developing world both immediately and in the future. As global capital flows - and their risks - remain prominent, the risks to stability arising from the absence of a durable and complete international financial architecture will likely become more evident . 


\section{$\underline{\text { Data Appendix }}$}

Most of the data underlying this paper was used in our previous work (Bordo and Meissner 2007a and 2007b and Bordo and Meissner 2006) and is explained thoroughly in those sources. The bulk of the macro historical data set is that used in Bordo et. al. (2001). Even more expansive data descriptions and sources are listed in the working paper versions of our earlier work on crises in NBER working papers 11173 and 11897 and available upon request from the authors.

\section{Country Sample:}

Countries included in Empirical Samples, First Wave

\begin{tabular}{|l|l|}
\hline Set 1. Growth Regressions & $\mathrm{n}=19$ countries include Argentina, Australia, Austria, \\
& $\begin{array}{l}\text { Brazil, Canada, Chile, Denmark, France, Germany, } \\
\text { Greece, India Italy, Japan, Norway, Portugal, Russia, } \\
\text { Sweden, Spain, United States. }\end{array}$ \\
\hline Set 2. Crisis Regressions & $\mathrm{n}=18$, countries include Argentina, Australia, Austria, \\
& Brazil, Canada, Chile, Denmark, France, Germany, \\
& Greece, Italy, Japan, Norway, Portugal, Russia, \\
& Sweden, Spain, United States. \\
\hline
\end{tabular}

\begin{tabular}{|l|l|}
\hline \multicolumn{2}{|l|}{ Countries included in Empirical Samples, Second Wave } \\
\hline Set 1. Growth Regressions & n=49, countries include Argentina, Australia, Austria, \\
& Bangladesh, Belgium, Brazil, Canada, Chile, China, \\
& Colombia, Costa Rica, Denmark, Ecuador, Egypt, \\
& Finland, France, Germany, Ghana, Greece, Hong \\
& Kong, Iceland, India, Indonesia, Ireland, Israel, Italy, \\
& Jamaica, Japan, Malaysia, Mexico, Netherlands, New \\
& Zealand, Norway, Pakistan, Paraguay, Peru, \\
& Philippines, Portugal, Senegal, South Africa, Spain, \\
& Sweden, Switzerland, Turkey, United Kingdom, \\
& United States, Uruguay, Venezuela, Zimbabwe \\
\hline Set 2. Crisis Regressions & n=45, countries include Argentina, Australia, Austria, \\
& Belgium, Brazil, Canada, Chile, China, Colombia, \\
& Costa Rica, Denmark, Ecuador, Finland, France, \\
& Germany, Ghana, Greece, Iceland, India, Indonesia, \\
& Ireland, Israel, Italy, Jamaica, Japan, Malaysia, \\
& Mexico, Netherlands, New Zealand, Norway, \\
& Pakistan, Peru, Philippines, Portugal, South Africa, \\
& Spain, Sweden, Switzerland, Turkey, United \\
& Kingdom, United States, Uruguay, Venezuela, \\
& Zimbabwe \\
& \\
\hline
\end{tabular}




\section{Crisis Dating:}

As in Bordo et. al ( 2001) we date currency and banking crises using both qualitative and quantitative evidence. For all countries besides Austria-Hungary, Russia, New Zealand, South Africa, Mexico, Turkey, Egypt, Uruguay and India we have relied on the dates of Bordo et. al. in both periods. We have tried to date currency crises for the $19^{\text {th }}$ century, when possible, by using an approach based on the exchange market pressure (EMP) methodology which looks at changes in reserves, the exchange rate and the interest rate. Currency crises past 1997 have been updated using the dates from Kaminsky (2006). Banking crises are listed in Bordo et. al. and updated past 1997 from Caprio and Klingebiel (2003).

Debt crisis dates are based on Beim and Calomiris (2001). Only private lending to sovereign nations is considered when building those default dates. Not every instance of technical default is included in the chronology, the authors identified periods (six months or more) where all or part of interest/principal payments were suspended, reduced or rescheduled. Some of those episodes are outright debt repudiations, while others were reschedulings agreed upon mutually by lenders and borrowers. Additional data are from a spreadsheet underlying Reinhart, Rogoff and Savastano (2003). Post-1997 we code the following as debt crises: Pakistan (1999), Ecuador (1999) Indonesia (1999), and Argentina (2001).

\section{Capital Inflows}

Our measure of international capital market integration for the 1880-1913 period is based on Stone's (1999) total capital calls on the London market which includes public and private issues of debt purged of any refinancing issues. ${ }^{38}$ The conventional wisdom for the period is that these gross flows were roughly equal to net flows for the capital importers (cf. Obstfeld and Taylor, 2004). ${ }^{39}$

\footnotetext{
${ }^{38}$ We also carried out tests (which are left unreported), using the current account relative to GDP as a measure of the net inflow or outflow of capital.

${ }^{39}$ The correlation between Stone's flows and the current account deficits is 0.69 .
} 
The data for 1973-2003 are based on Lane and Milesi-Ferretti (2006). We use the change in the net economic position (NEP) as a measure of net inflows of foreign capital.

\section{Ratio of International Reserves to Money}

Source: International financial statistics IMF.

\section{$\underline{\text { Hard Currency Debt Ratios }}$}

For the 1880-1913 period, we collected data from various national sources on hard currency debt for domestic governments (cf. Bordo and Meissner, 2007a) and augmented and compared this with similar data made available by Flandreau and Zúmer (2004). What we refer to as hard currency debt (or original sin) is debt that carried a gold clause or was made payable at a fixed rate in a foreign currency issued domestically or externally. ${ }^{40}$ Our measure of original sin, $O S$, is the ratio of this quantity to total public debt outstanding:

$$
O S_{i}=\max \left(1-\frac{\text { Securities issued in currency } \mathrm{i} \text { by country } \mathrm{i}}{\text { Securities issued by country } \mathrm{i}}, 0\right) \text {. }
$$

For the current period we rely on data underlying Eichengreen, Hausman and Panizza (2005) and thank the authors for making these data available to us. These data reflect public and private obligations issued on external or international markets only and exclude domestic debt issues. Note that these data are within country averages for the period 1972-1997.

\section{Data for Table 7}

Foreign Currency Debt/Total Debt is calculated as the percentage of total household loans denominated in foreign currency as of January 2008. Source: Fitch Ratings see "Emerging Europe's Current Account Deficits: Mind the Gap!" (2008);

Short term interest rates are the yields on 6 month US treasury bills as of March 20, 2009.

\footnotetext{
${ }^{40}$ The data appendices and the text in our previous work on crises has more to say about the structure of this debt.
} 
Data on the net international investment position (NIIP) come from the statistical services and central banks of the respective countries listed in the table. The following applies: NIIP for Czech Republic is for June 2008 and June 2007; NIIP for Slovakia is year end 2007 and 2008. growth rate for GDP between 2007 and 2008 was extrapolated as 8 percent since final 2008 figures for GDP were not yet available. NIIP for Poland is for 2006 and 2007; NIIP for Romania is for year end 2007 and 2008; NIIP for Bulgaria is as of June 2007 and 2008; NIIP for Lithuania is as of year end 2007 and 2008; NIIP for Hungary is year end 2006 and 2007; NIIPs for Estonia and Latvia are year end 2007 and 2008.

The ratios of reserves/money come from International Financial Statistics January 2009 International Monetary Fund, Washington, DC.

Country specific notes:

Czech Republic: Notes: Reserves and M2 as of Oct. 2008;

Slovakia: Reserves and M2 as of August 2008;

Poland: Reserves and M2 as of September 2008

Romania: Reserves, M2,as of October 2008;

Bulgaria: Reserves, M2, as of October 2008;

Lithuania: Reserves, money as of October 2008

Hungary: Reserves, M2, exchange rate as of October 2008;

Estonia: Reserves, M2, exchange rate as of October 2008;

Latvia: Reserves, M2 exchange rates as of October 2008. 


\section{$\underline{\text { References }}$}

Aghion, P., Bachhetta, P., and Banerjeee, A., 2000. A Simple Model of Monetary Policy and Currency Crises. European Economic Review 44 (4-6), 728-738.

Arteta, C., 2003. Are Financially Dollarized Countries More Prone to Costly Crises? Board of Governors of the Federal Reserve System, International Finance Discussion Papers no. 763. Washington, D.C.

Bebczuk, R., Galindo, A., and Panizza, U., 2006. An Evaluation of the Contractionary Devaluation Hypothesis Inter-American development bank working paper no. 582. Washington, D.C.

Bekaert, G., Campbell H., and Lundblad, C., 2005. Does Financial Liberalization Spur Growth? Journal of Financial Economics 77 (1), 3-55.

Beim, D. O., Calomiris, C.W., 2001. Emerging Financial Markets MacGraw-Hill, New York.

Bleakley, H., and Cowan, K., 2008. Corporate Dollar Debt and Depreciations: Much Ado About Nothing? Review of Economics and Statistics 90 (4), 612-626.

Bordo, M.D., Eichengreen, B., Klingebiel. D., Martinez-Peria, M.S., 2001. Is the Crisis Problem Growing More Severe? Economic Policy 32 pp. 51-75.

Bordo, M.D., Cavallo, A. Meissner, C.M., forthcoming. Sudden Stops: Determinants and Output Effects in the First Era of Globalization, 1880-1913 Journal of Development Economics.

Bordo, M.D., Meissner, C.M., 2007a. Financial Crises, 1880-1913: The Role of Foreign Currency Debt. In: Edwards, S., Esquivel, G., Márquez, G. (Eds.), The Decline of Latin American Economies: Growth, Institutions, and Crises, University of Chicago Press, Chicago, pp. 139-194.

Bordo, M.D., Meissner, C.M., 2007b. Foreign Capital and Economic Growth in the First Era of Globalization NBER Working Paper 13577. Cambridge, Mass.

Bordo, M.D., Meissner, C.M., 2006. The Role of Foreign Currency Debt in Financial Crises: 18801913 vs. 1972-1997. Journal of Banking and Finance 60, 3299-3329.

Bordo, M.D., Meissner, C.M., Redish, A., 2005. How 'Original Sin' was overcome: the evolution of external debt denominated in domestic currencies in the United States and the British Dominions 1800-2000. in Eichengreen, B., Hausmann, R. (Eds.), Other People's Money University of Chicago Press, Chicago, pp. 122-153. 
Burger, J.D., Warnock, F.E., 2006. Local Currency Bond Markets. IMF Staff Papers 53, 115-132.

Caballero, R.J. and Krishnamurthy,A., 2003. Excessive Dollar Debt: Financial Underdevelopment and Underinsurance. Journal of Finance 58 (2), 867-893.

Calvo, G. A., Izquierdo, A. Mejia, L.F., 2004. On the Empirics of Sudden Stops: The Relevance of Balance-Sheet Effects. National Bureau of Economic Research Working Paper Series No. 10520, Cambridge, Mass.

Calvo, G.A., Reinhart, C., 2002 Fear Of Floating. Quarterly Journal of Economics 107 (2,May), 379-408.

Calvo, G., Izquierdo, A., Talvi, E., 2006. Sudden Stops and Pheonix Miracles in Emerging Markets. American Economic Review Papers and Proceedings 96 (2), 405410.

Caprio G, Klingebiel, D., 2003. Episodes of Systemic and Borderline Financial Crises. World Bank: Washington D.C. Available at http://econ.worldbank.org/WBSITE/EXTERNAL/EXTDEC/EXTRESEARCH/0,,content MDK:20699588 pagePK:64214825 piPK:64214943 theSitePK:469382,00.html.

Céspedes, L. F., Chang, R., Velasco, A., 2004. Balance Sheets and Exchange Rate Policy. American Economic Review 94 (4), 1183-1193.

Clemens, M.A., Williamson, J.G., 2004. Wealth Bias in the First Global Capital Market Boom, 1870-1913. Economic Journal 114, 304-337

Cottrell, P. L., 1975. British overseas investment in the nineteenth century. Macmillan, London.

Eichengreen, B., 2002. Financial Crises: And What to do About Them. Oxford University Press, New York.

Eichengreen, B., Hausmann, R., 1999. Exchange Rates and Financial Fragility. New Challenges for Monetary Policy Federal Reserve Bank of Kansas City, pp. 329-368.

Eichengreen, B., Hausmann, R., Panizza, U., 2003. Currency Mismatches, Debt Intolerance, and Original Sin: Why they are not the Same and Why it Matters. NBER working paper 10036, Cambridge, Mass.

Eichengreen, B., Hausmann, R. Panizza, U., 2005. The Pain of Original Sin, In:

Eichengreen, B., Hausmann, R. (Eds.), Other People's Money. University of Chicago

Press, Chicago, pp. 13-47. 
Feldstein, M., 2009. Reflections on Americans' views of the Euro ex ante. vox EU http://www.voxeu.org/index.php?q=node/2867

Fitch Ratings, 2008. Emerging Europe's Current Account Deficits: Mind the Gap! Fitch Research: New York.

Flandreau, M., Zúmer, F., 2004. The Making of Global Finance. OECD: Paris.

Flandreau, M., Sussman, N., 2005. Old Sins. In: Eichengreen, B. and Hausmann, R. (Eds.), Other People's Money, University of Chicago Press, Chicago, pp 154-189.

Gligorov, V., Landesmann, M.A., 2009. The crisis in Eastern Europe: What is to be done? VOX EU web portal. 16 March, 2009. http://www.voxeu.org/index.php?q=node/3274.

Goldstein, M., Turner, P. 2004. Controlling Currency Mismatches in Emerging Market Economies. Institute of International Economics: Washington.

Gros, D., 2009. Collapse in Eastern Europe? The rationale for a European Financial Stability. Roubini Global Monitor. 1 March, 2009 http://www.rgemonitor.com/globalmacromonitor/255737/collapse_in_eastern_europe_the_rationale_for_a_european_financial_sta bility

Jeanne, O., 2000. Foreign Currency Debt and the Global Financial Architecture. European Economic Review 44, 719-727.

Jeanne, O. Zettlemeyer, J., 2005. Original Sin, Balance Sheet Crises and International Lending. In: Eichengreen, B. and Hausmann, R. (Eds.), Other People's Money, University of Chicago Press, Chicago, pp. 95-121.

Kaminsky, G., 2006. Currency crises: Are they all the same? Journal of International Money and Finance. 25 (3), 503-527.

Krugman, P., 1999. Balance Sheets, the Transfer Problem and Financial Crises. In: Isard, P. Razin, A., Rose, A., International Finance and Financial Crises. Kluwer, New York.

Lane, P.. Milesi-Ferretti, G.M., 2006. The External Wealth of Nations Mark II: Revised and Extended Estimates of Foreign Assets and Liabilities, 1970-2004. IMF working paper no. 06/69. Washington, DC.

Mankiw, G. Romer, D., Weil, D.N., 1992. A Contribution to the Empirics of Economic Growth. Quarterly Journal of Economics 107 (2), 407- 437. 
Mauro, P., Sussman, N. Yafeh, Y., 2006. Emerging Markets and Financial Globalization: Sovereign Bond Spreads in 1870-1913 and Today. Oxford University Press, New York.

Mishkin, F. S., 2003. Financial Policies and the Prevention of Financial Crises in Emerging Market Countries. In: Feldstein, M. (Ed.) Economic and Financial Crises in Emerging Markets. University of Chicago Press, Chicago, pp. 93-130.

Obstfeld, M., Taylor. A.M., 2004. Global Capital Markets: Integration, Crisis, and Growth. Cambridge University Press, New York.

Pesaran, M.H. Smith, R. 1995. Estimating Long-Run Relationships from Dynamic Heterogeneous Panels. Journal of Econometrics 68, 79-113.

Rancière, R. Tornell, A. Westerman, F., 2006. Decomposing the Effects of Financial Liberalization: Growth vs Crises. Journal of Banking and Finance 30 (12), 3331-3348.

Rancière, R. Tornell, A. (2009) "Financial Liberalization, Boom-Bust Cycles and Production Efficiency" unpublished working paper, University of California, Los Angeles, Los Angeles, CA.

Reinhart, C., Rogoff, K., 2008. The Forgotten History of Domestic Debt," unpublished working paper, University of Maryland, ***.

Reinhart, C., Rogoff, K., Savastano, M., 2003. Debt Intolerance.

Brookings Papers on Economic Activity 1, 1-74.

Rosenberg, C., 2008. Foreign Currency Borrowing More Risky for Eastern Europe. IMF website http://www.imf.org/external/pubs/ft/survey/so/2008/car102808a.htm

Rousseau, P. Sylla, R., 2003. Financial Systems, Economic Growth, and Globalization. In: Bordo, M. D., Taylor, A., Williamson, J.G., (Eds.) Globalization in Historical Perspective. University of Chicago Press for the National Bureau of Economic Research, Chicago, pp. 373-413.

Stokes, M., 2009. Eastern Europe: On Crisis Watch Roubini Global Monitor. http://www.rgemonitor.com/euro-monitor/255488/eastern_europe_on_crisis_watch

Stone, I., 1999. The Global Export of Capital from Great Britain, 1865-1914. St-Martin's Press, New York.

Svedberg, P., 1978., The portfolio direct composition of private foreign investment in 1914 Revisited. Economic Journal 88, 763-777.

Taylor, A.M., 2002. A Century of Current Account Dynamics. Journal of International Money and Finance, 21 (6), 725-748. 
Williamson, J.G., 1964. American Growth and The Balance of Payments University of North Carolina Press Chapel Hill. 
Figure 1 Framework for Balance Sheet Crises

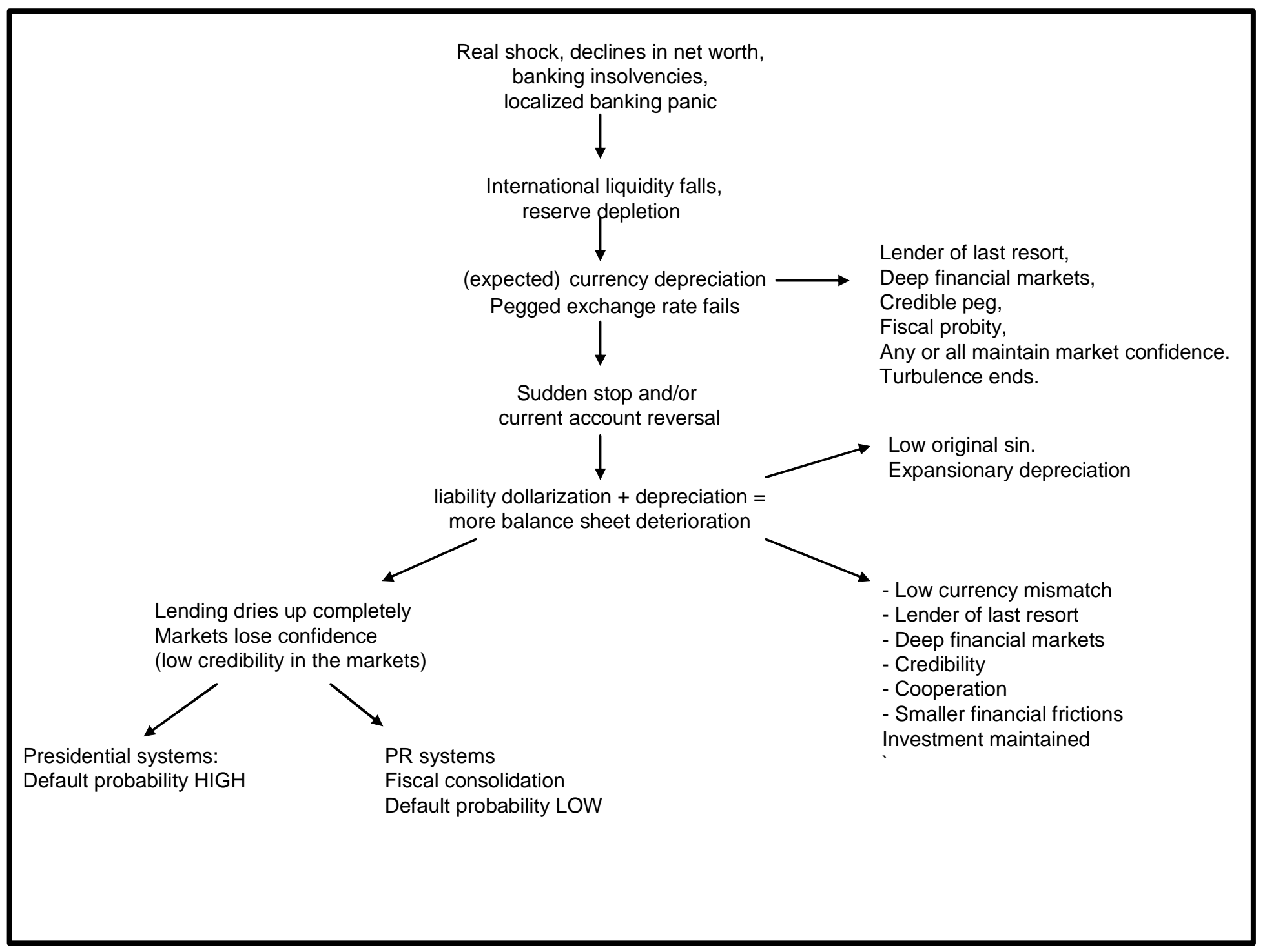


Figure 2 Average Current Account/GDP Ratios for Selected Eastern European

Nations, 1998-2008

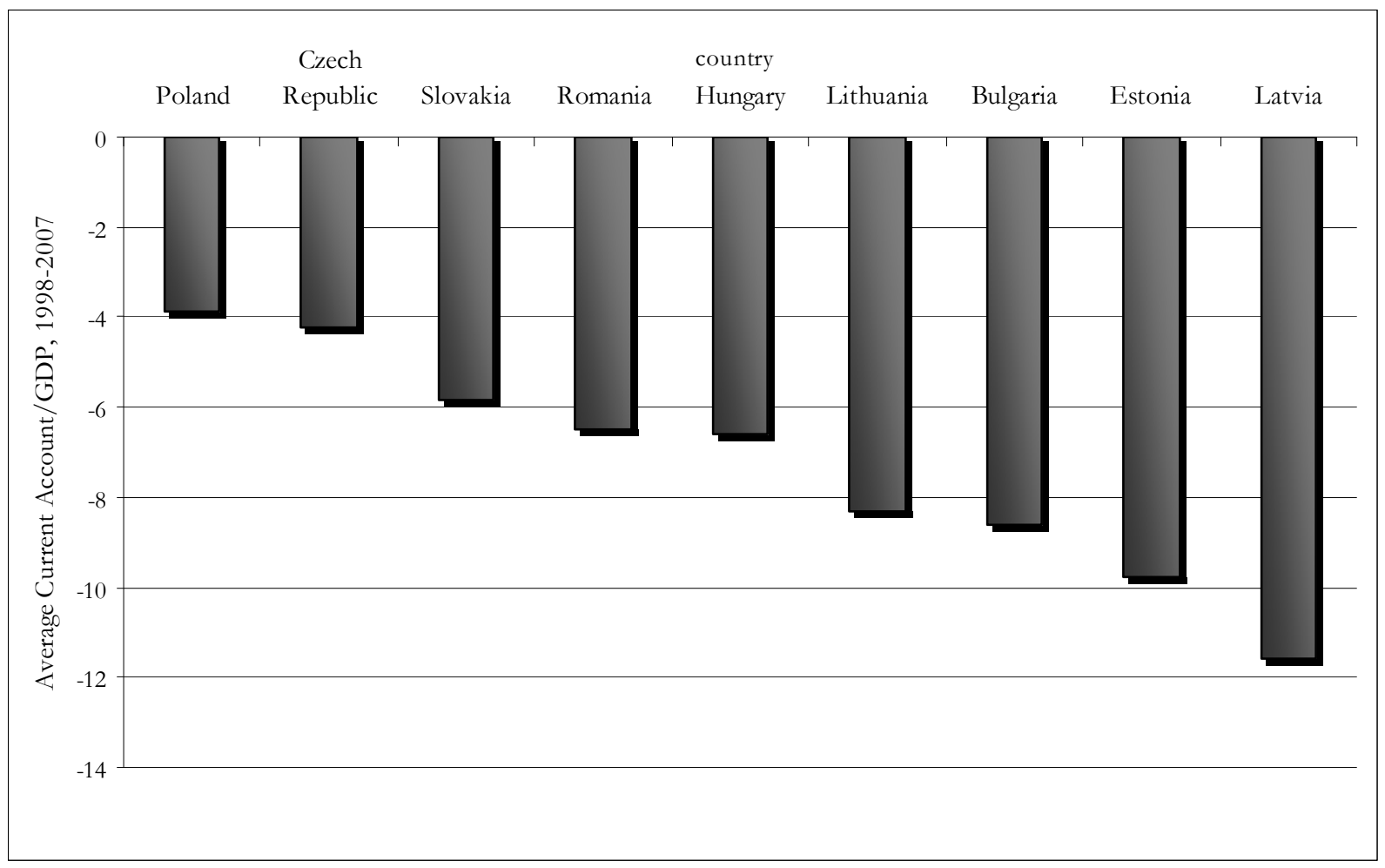




\begin{tabular}{|c|c|c|c|c|c|c|}
\hline \multicolumn{7}{|c|}{ Table 1 Determinants of Financial Crises, Full Sample } \\
\hline \multirow[b]{2}{*}{ Covariates } & \multicolumn{3}{|c|}{$\begin{array}{l}\text { First Wave of Market Integration } \\
1880-1913\end{array}$} & \multicolumn{3}{|c|}{$\begin{array}{c}\text { Second Wave of Market Integration } \\
1973-2003\end{array}$} \\
\hline & $\begin{array}{c}(1) \\
\text { Currency }\end{array}$ & $\begin{array}{c}(2) \\
\text { Debt }\end{array}$ & $\begin{array}{c}\text { (3) } \\
\text { Avg. } \\
\text { value }^{a}\end{array}$ & $\begin{array}{c}\text { (4) } \\
\text { Currency }\end{array}$ & $\begin{array}{l}(5) \\
\text { Debt }\end{array}$ & $\begin{array}{c}\text { (6) } \\
\text { Avg. } \\
\text { value }^{a}\end{array}$ \\
\hline $\begin{array}{l}\text { Lag of Level of Net } \\
\text { Inflows/GDP }\end{array}$ & $\begin{array}{c}0.003 * * * \\
(0.001)\end{array}$ & - & 1.79 & $\begin{array}{c}0.0018 \\
(0.0011)^{*}\end{array}$ & - & 0.75 \\
\hline Original Sin & $\begin{array}{l}-0.00008 \\
(0.00022)\end{array}$ & $\begin{array}{l}-0.00006 \\
(0.00005)\end{array}$ & 52.46 & $\begin{array}{c}0.0013^{* * * *} \\
(0.00040)\end{array}$ & $\begin{array}{l}0.00054^{*} \\
(0.00016)\end{array}$ & 78.4 \\
\hline $\begin{array}{l}\text { Original Sin x Currency } \\
\text { Crisis }\end{array}$ & - & $\begin{array}{l}0.0003^{*} \\
(0.0002)\end{array}$ & 2.05 & - & $\begin{array}{c}0.0020 \\
(0.0033)\end{array}$ & 5.69 \\
\hline $\begin{array}{l}\text { Lag of Short term real } \\
\text { UK/US Interest Rate }\end{array}$ & $\begin{array}{l}0.021 * * \\
(0.009)\end{array}$ & $\begin{array}{l}-0.0020 \\
(0.0013)\end{array}$ & 2.75 & $\begin{array}{c}0.0031 \\
(0.0018)\end{array}$ & $\begin{array}{l}0.0025^{* *} \\
(0.0011)\end{array}$ & 6.6 \\
\hline Lag of Reserves/Money & $\begin{array}{c}-0.0004 * * \\
(0.0002)\end{array}$ & $\begin{array}{l}-0.0002 \\
(0.0001)\end{array}$ & 48.46 & $\begin{array}{l}-0.000053 \\
(0.000100)\end{array}$ & $\begin{array}{l}-0.000075 \\
(0.000069)\end{array}$ & 57.97 \\
\hline Lag of Bank Crisis & $\begin{array}{c}0.04 \\
(0.06)\end{array}$ & $\begin{array}{l}0.03 * * \\
(0.02)\end{array}$ & 0.05 & $\begin{array}{c}0.054 * * * \\
(0.024)\end{array}$ & $\begin{array}{c}0.014^{* *} \\
(0.010)\end{array}$ & 0.12 \\
\hline Currency Crisis & - & $\begin{array}{l}-0.003 \\
(0.005)\end{array}$ & 0.04 & - & $\begin{array}{l}-0.029 \\
(0.041)\end{array}$ & 0.059 \\
\hline Country-Years & 508 & 508 & & 1252 & 1252 & \\
\hline Countries & 18 & 18 & & 45 & 45 & \\
\hline Obs. P & 0.04 & 0.012 & & 0.06 & 0.03 & \\
\hline Pred. P (at x-bar) & 0.03 & 0.005 & & 0.04 & 0.01 & \\
\hline Pseudo- $\mathrm{R}^{2}$ & 0.11 & 0.22 & & 0.08 & 0.13 & \\
\hline
\end{tabular}

Notes: Standard errors in parentheses are clustered by country; Marginal effects of explanatory variables on the probability of a crisis are shown, not coefficients. Countries included in the first wave sample are Argentina, Australia, Austria, Brazil, Canada, Chile, Denmark, France, Germany, Greece, Italy, Japan, Norway, Portugal, Russia, Sweden, Spain, United States. Countries included in the second wave sample are Argentina, Australia, Austria, ,Belgium, Brazil, Canada, Chile, China, Colombia, Costa Rica, Denmark, Ecuador, Finland, France, Germany, Ghana, Greece, Iceland, India, Indonesia, Ireland, Israel, Italy, Jamaica, Japan, Malaysia, Mexico, Netherlands, New Zealand, Norway, Pakistan, Peru, Philippines, Portugal, South Africa, Spain, Sweden, Switzerland, Turkey, United Kingdom, United States, Uruguay, Venezuela, RB, Zimbabwe

${ }^{\mathrm{a}}$ - based on currency crisis sample

Significance at $*-p<0.10, * *-p<0.05, * * *-p<0.01$ 


\begin{tabular}{|c|c|c|}
\hline \multirow[b]{2}{*}{ Economic Conditions } & \multicolumn{2}{|c|}{$\operatorname{Pr}$ (Debt Crisis) } \\
\hline & $\begin{array}{l}\text { First Wave } \\
1880-1913\end{array}$ & $\begin{array}{c}\text { Second Wave } \\
1973-2003\end{array}$ \\
\hline $\begin{array}{l}\text { Scenario \#1: Excellent Fundamentals } \\
\text { Original Sin }=100 \\
\text { Original Sin x Currency Crisis = } \\
\text { Gold Coverage Ratio }=\text { Average } \\
\text { Currency Crisis }=0 \\
\text { Bank Crisis Last Year }=0\end{array}$ & $<0.01$ & 0.03 \\
\hline $\begin{array}{l}\text { Scenario } \# 2 \text { : Good Fundamentals } \\
\text { Original Sin = } 100 \\
\text { Original Sin x Currency Crisis = } 100 \\
\text { Gold Coverage Ratio = Average } \\
\text { Currency Crisis }=1 \\
\text { Bank Crisis Last Year }=0 \\
\end{array}$ & 0.20 & 0.08 \\
\hline $\begin{array}{l}\text { Scenario \#3: Bad Fundamentals } \\
\text { Original Sin }=100 \\
\text { Original Sin } \mathrm{x} \text { Currency Crisis }=0 \\
\text { Gold Coverage Ratio }=0 \\
\text { Currency Crisis }=0 \\
\text { Bank Crisis Last Year }=1 \\
\end{array}$ & 0.08 & 0.07 \\
\hline $\begin{array}{l}\text { Scenario \#4: Worst Fundamentals } \\
\text { Original Sin }=100 \\
\text { Original Sin } x \text { Currency Crisis }=100 \\
\text { Gold Coverage Ratio }=0 \\
\text { Currency Crisis }=1 \\
\text { Bank Crisis Last Year }=1\end{array}$ & 0.63 & 0.18 \\
\hline
\end{tabular}




\begin{tabular}{|c|c|c|c|c|c|c|}
\hline \multicolumn{7}{|c|}{ Table 3 Determinants of Financial Crises, Instrumental Variables } \\
\hline \multirow[b]{2}{*}{ Covariates } & \multicolumn{3}{|c|}{$\begin{array}{l}\text { First Wave of Market Integration } \\
1880-1913\end{array}$} & \multicolumn{3}{|c|}{$\begin{array}{c}\text { Second Wave of Market Integration } \\
1973-2003\end{array}$} \\
\hline & $\begin{array}{c}(1) \\
\text { Currency }\end{array}$ & $\begin{array}{c}(2) \\
\text { Debt }\end{array}$ & $\begin{array}{c}\text { (3) } \\
\text { Avg. } \\
\text { value }\end{array}$ & $\begin{array}{c}\text { (4) } \\
\text { Currency }\end{array}$ & $\begin{array}{c}(5) \\
\text { Debt }\end{array}$ & $\begin{array}{c}\text { (6) } \\
\text { Avg. } \\
\text { value }\end{array}$ \\
\hline $\begin{array}{l}\text { Lag of Level of Net } \\
\text { Inflows/GDP }\end{array}$ & $\begin{array}{c}0.06^{* * * *} \\
(0.02)\end{array}$ & - & 1.79 & $\begin{array}{l}0.03 * * \\
(0.01)\end{array}$ & - & 0.75 \\
\hline Original Sin & $\begin{array}{l}-0.003 \\
(0.008)\end{array}$ & $\begin{array}{l}-0.002 \\
(0.01)\end{array}$ & 52.46 & $\begin{array}{c}0.002 \\
(0.007)\end{array}$ & $\begin{array}{l}0.02 * * \\
(0.009)\end{array}$ & 78.4 \\
\hline $\begin{array}{l}\text { Original Sin x Currency } \\
\text { Crisis }\end{array}$ & - & - & - & - & - & - \\
\hline $\begin{array}{l}\text { Lag of Short term real } \\
\text { UK/US Interest Rate }\end{array}$ & $\begin{array}{l}0.29 * * \\
(0.13)\end{array}$ & $\begin{array}{l}-0.14 \\
(0.12)\end{array}$ & 2.75 & $\begin{array}{c}0.03 \\
(0.02)\end{array}$ & $\begin{array}{c}0.08 * * * \\
(0.02)\end{array}$ & 6.6 \\
\hline Lag of Reserves/Money & $\begin{array}{l}-0.005^{*} \\
(0.003)\end{array}$ & $\begin{array}{l}-0.01 \\
(0.01)\end{array}$ & 48.46 & $\begin{array}{l}-0.0009 \\
(0.001)\end{array}$ & $\begin{array}{l}-0.002^{*} \\
(0.002)\end{array}$ & 57.97 \\
\hline Lag of Bank Crisis & $\begin{array}{c}0.49 \\
(0.48)\end{array}$ & $\begin{array}{l}0.93 * * \\
(0.48)\end{array}$ & 0.05 & $\begin{array}{c}0.59 * * * \\
(0.13)\end{array}$ & $\begin{array}{c}0.21 \\
(0.18)\end{array}$ & 0.12 \\
\hline Currency Crisis & - & $\begin{array}{r}1.08 * * \\
(0.47)\end{array}$ & 0.04 & - & $\begin{array}{l}0.39 * * \\
(0.19)\end{array}$ & 0.059 \\
\hline Country-Years & 503 & 503 & & 1252 & 1252 & \\
\hline Countries & 18 & 18 & & 45 & 45 & \\
\hline $\begin{array}{l}\text { Wald test for exogeneity } \\
\text { (p-value) }\end{array}$ & 0.74 & 0.96 & & $0.001 * * *$ & $0.05 * *$ & \\
\hline $\begin{array}{l}\text { Chi-squared test for zero } \\
\text { slopes (p-value) }\end{array}$ & $0.000 * * *$ & $0.04 * *$ & & $0.0001 * * *$ & $0.000 * * *$ & \\
\hline & & & & & & \\
\hline
\end{tabular}

Notes: Estimation is by one-step maximum likelihood for probit models with endogenous regressors. Probit coefficients are shown. Excluded instruments for original sin in the first wave are the logarithm of GDP and an indicator for being in the British Empire. In the second wave the excluded instrument is the logarithm of GDP. Standard errors in parentheses are clustered by country; Countries included in the samples are those listed in Table 1.

Significance at $*$ - $p<0.10, * *-p<0.05, * * *-p<0.01$ 


\begin{tabular}{|l|c|c|c|c|c|c|}
\hline \multicolumn{7}{|c|}{ Table 4 Determinants of Financial Crises, Robustness to Sample Changes with and without Instrumental } \\
Variables, $1973-2003$
\end{tabular}

Notes: Estimation in columns (1) and (2) are probit models. Estimation in columns (4) and (5) are by onestep maximum likelihood for probit models with endogenous regressors. The excluded instrument for original sin is the logarithm of GDP. Standard errors in parentheses are clustered by country; Countries included in the samples are those listed in Table 1 for the second wave with out the G-7 and Switzerland. Significance at $*-p<0.10, * *-p<0.05, * * *-p<0.01$ 
Table 5 International Financial Integration and Growth, Five Year Periods, 1880-1910 and 1972-2003

Dependent Variable: Average Five Year Percentage Growth Rate of GDP per Capita in non-overlapping periods

\begin{tabular}{|c|c|c|c|c|}
\hline \multirow[t]{2}{*}{ Covariates } & \multicolumn{2}{|c|}{$\begin{array}{c}\text { First Wave of Market } \\
\text { Integration } \\
1880-1910 \\
\end{array}$} & \multicolumn{2}{|c|}{$\begin{array}{c}\text { Second Wave of Market } \\
\text { Integration } \\
1973-2003\end{array}$} \\
\hline & (I) & (II) & (III) & (IV) \\
\hline Avg. Net Capital & -0.022 & 0.11 & -0.0038 & 0.014 \\
\hline Inflows/GDP & $(0.118)$ & $(0.12)$ & $(0.033)$ & $(0.036)$ \\
\hline Avg. Years in Crisis $\neq$ & $\begin{array}{l}-0.91 \\
(0.67)\end{array}$ & $\begin{array}{c}-2.84 * * \\
(1.15)\end{array}$ & $\begin{array}{c}-1.51 * * * \\
(0.41)\end{array}$ & $\begin{array}{c}-1.37 * * * \\
(0.37)\end{array}$ \\
\hline $\begin{array}{l}\text { Avg. Percentage School } \\
\text { Enrollment }\end{array}$ & $\begin{array}{c}0.24 \\
(0.24)\end{array}$ & $\begin{array}{c}0.64 * * \\
(0.22)\end{array}$ & $\begin{array}{c}0.028 \\
(0.029)\end{array}$ & $\begin{array}{c}0.038 \\
(0.032)\end{array}$ \\
\hline Avg. Exports/GDP & $\begin{array}{c}0.02 \\
(0.04)\end{array}$ & $\begin{array}{c}0.02 \\
(0.14)\end{array}$ & $\begin{array}{l}0.049 * * * \\
(0.018)\end{array}$ & $\begin{array}{l}0.036 * * \\
(0.017)\end{array}$ \\
\hline $\begin{array}{l}\text { Avg. Population Growth } \\
\text { Rate }\end{array}$ & $\begin{array}{l}-0.28 \\
(0.80)\end{array}$ & $\begin{array}{c}0.75 \\
(0.97)\end{array}$ & $\begin{array}{l}0.064 \\
(0.41)\end{array}$ & $\begin{array}{l}0.043 \\
(0.42)\end{array}$ \\
\hline Average Saving/GDP & - & $\begin{array}{l}-0.06 \\
(0.10)\end{array}$ & - & $\begin{array}{l}0.12 * * * \\
(0.043)\end{array}$ \\
\hline $\begin{array}{l}\text { Ln GDP per capita in first } \\
\text { year of } 5 \mathrm{yr} \text { period }\end{array}$ & $\begin{array}{l}-5.31 * \\
(2.96)\end{array}$ & $\begin{array}{l}-4.49 \\
(4.96)\end{array}$ & $\begin{array}{l}-4.79 * * * \\
(1.41)\end{array}$ & $\begin{array}{l}-5.90 * * * \\
(1.51)\end{array}$ \\
\hline Constant & $\begin{array}{l}36.91 * \\
(20.35)\end{array}$ & $\begin{array}{c}27.15 \\
(38.19)\end{array}$ & $\begin{array}{c}43.33 \\
(12.78)\end{array}$ & $\begin{array}{c}51.33 \\
(13.53)\end{array}$ \\
\hline $\begin{array}{l}\text { Mean Country Growth } \\
\text { Rate (\% per year) (std. } \\
\text { dev) }\end{array}$ & & & & \\
\hline $\begin{array}{l}\text { Mean Years in crisis (std. } \\
\text { dev) }\end{array}$ & & & & \\
\hline Number of country years & 105 & 62 & 254 & 254 \\
\hline Number of Countries & 18 & 12 & 49 & 49 \\
\hline $\mathrm{R}^{2}$-within & 0.26 & 0.43 & 0.30 & 0.33 \\
\hline
\end{tabular}

Notes: Country fixed effects models with robust standard errors clustered by country in parentheses. Models for each wave include dummies for years 1880, 1885, 1890, 1895, 1900, 1905, 1910 and 1973, 1978, 1983, 1988, 1993, and 1998, respectively. $\ddagger$ - Average years of financial crisis is the average of the sum of dummies for whether a country experienced a currency, banking, or debt crisis. Hausman-Taylor $\chi^{2}=10.68(\mathrm{p}<0.56)$ and $45.95(\mathrm{p}<0.001)$ for first and second waves respectively, favors fixed effects over random effects for second wave. Significance at $*$ - $_{p}<0.10, * *-p<0.05, * * *-p<0.01$ 
Table 6 International Financial Integration, Crises and Growth, Long and Short-Run Impacts on Output per capita, 1880-1910 and 1972-2003

\begin{tabular}{|c|c|c|c|c|}
\hline \multirow[b]{2}{*}{ Covariates } & \multicolumn{2}{|c|}{$\begin{array}{l}\text { First Wave of Market Integration } \\
1880-1913\end{array}$} & \multicolumn{2}{|c|}{$\begin{array}{c}\text { Second Wave of Market Integration } \\
1973-2003\end{array}$} \\
\hline & $\begin{array}{c}\text { Short Run } \\
\text { Coefficients } \\
\text { (Change in } X)\end{array}$ & $\begin{array}{c}\text { Long Run } \\
\text { Coefficients } \\
\text { (Levels of } X \text { ) }\end{array}$ & $\begin{array}{l}\text { Short Run } \\
\text { Coefficients } \\
\text { (Change in } X)\end{array}$ & $\begin{array}{l}\text { Long Run } \\
\text { Coefficients } \\
(\text { Levels of } X)\end{array}$ \\
\hline Net Capital Inflows/GDP $(t)$ & $\begin{array}{l}0.26^{*} \\
(0.14)\end{array}$ & $\begin{array}{l}0.19 * \\
(0.08)\end{array}$ & $\begin{array}{l}-0.03 * \\
(0.01)\end{array}$ & $\begin{array}{c}-0.07 * * * \\
(0.02)\end{array}$ \\
\hline Net Capital Inflows/GDP $(t-1)$ & $\begin{array}{c}0.11 \\
(0.14)\end{array}$ & - & $\begin{array}{c}0.04 * * * \\
(0.01)\end{array}$ & - \\
\hline Net Capital Inflows/GDP ( $t-2)$ & - & - & $\begin{array}{c}0.03 * * \\
(0.01)\end{array}$ & - \\
\hline Crisis $(t)$ & $\begin{array}{l}-0.01 \\
(0.01)\end{array}$ & $\begin{array}{l}-0.04 * \\
(0.02)\end{array}$ & $\begin{array}{l}-0.017 * * * \\
(0.004)\end{array}$ & $\begin{array}{l}-0.015^{* * * *} \\
(0.004)\end{array}$ \\
\hline $\operatorname{Crisis}(t-1)$ & $\begin{array}{l}-0.003 \\
(0.01)\end{array}$ & - & $\begin{array}{l}-0.006 \\
(0.004)\end{array}$ & - \\
\hline Crisis $(t-2)$ & - & - & $\begin{array}{c}0.001 \\
(0.003)\end{array}$ & - \\
\hline Percentage School Enrollment & $\begin{array}{l}1.45 \\
(1.82)\end{array}$ & $\begin{array}{c}0.11 \\
(0.25)\end{array}$ & $\begin{array}{l}-0.04 \\
(0.004)\end{array}$ & $\begin{array}{c}0.0002 \\
(0.0002)\end{array}$ \\
\hline Exports/GDP & $\begin{array}{c}0.12 \\
(0.32)\end{array}$ & $\begin{array}{l}0.09 \\
(0.22)\end{array}$ & $\begin{array}{l}-0.02 \\
(0.03)\end{array}$ & $\begin{array}{l}0.0003 * * \\
(0.0001)\end{array}$ \\
\hline Population Growth Rate & $\begin{array}{c}0.29 \\
(0.53)\end{array}$ & $\begin{array}{l}-0.44 \\
(0.60)\end{array}$ & $\begin{array}{l}-0.42 \\
(0.36)\end{array}$ & $\begin{array}{l}-0.001 \\
(0.002)\end{array}$ \\
\hline Saving/GDP & $\begin{array}{l}0.25 \\
(0.13)\end{array}$ & $\begin{array}{c}0.1^{*} \\
(0.06)\end{array}$ & $\begin{array}{c}0.18 \\
(0.06)^{* * *}\end{array}$ & $\begin{array}{l}0.001 * * * \\
(0.0004)\end{array}$ \\
\hline $\begin{array}{l}\text { Growth GDP } \\
\text { per capita }(t-1)\end{array}$ & $\begin{array}{l}-0.28 \\
(0.05)\end{array}$ & - & $\begin{array}{c}0.1 \\
(0.05)^{*}\end{array}$ & - \\
\hline GDP per capita $(t-1)$ & - & $\begin{array}{l}-0.03 \\
(0.06)\end{array}$ & - & $\begin{array}{c}-0.05 \\
(0.01)^{* * *}\end{array}$ \\
\hline $\begin{array}{l}\text { Mean Country Growth Rate (\% } \\
\text { per year) (std. dev) }\end{array}$ & & & & \\
\hline Number of country years & & & & \\
\hline Number of Countries & & & & \\
\hline $\mathrm{R}^{2}$-within & & & & \\
\hline
\end{tabular}

Notes: Country dynamic country fixed effects models with robust standard errors clustered by country in parentheses. Dependent variable is the annual change in the natural logarithm of GDP per capita. See text for more discussion. Models for each wave include time dummies. Short-run coefficients are for annual changes in the explanatory variables. Long-run coefficients are for levels of the variables.

Significance at $*-p<0.10, * *-p<0.05, * * *-p<0.01$ 
Table 7 Eastern Europe, Predicted Probabilities of Crises and Expected Growth Losses as of March, 2009

\begin{tabular}{|c|c|c|c|c|c|c|c|c|c|}
\hline & Czech Republic & Slovakia & Poland & Romania & Bulgaria & Lithuania & Hungary & Estonia & Latvia \\
\hline Capital Inflows/GDP $(-1 \mathrm{x}$ change in NIIP) & 7.21 & 2.50 & 4.51 & 19.23 & 21.93 & 8.96 & 4.64 & 0.36 & 36.95 \\
\hline Foreign Currency Debt/Total Debt & 12 & 14 & 22 & 53 & 55 & 58 & 62 & 78 & 85 \\
\hline Original Sin x Foreign Currency Debt/Total Debt & 12 & 14 & 22 & 53 & 55 & 58 & 62 & 78 & 85 \\
\hline Short term interest rate & 0.38 & 0.38 & 0.38 & 0.38 & 0.38 & 0.38 & 0.38 & 0.38 & 0.69 \\
\hline Reserves/M2 & 25.45 & 35.54 & 27.26 & 61.69 & 59.14 & 37.93 & 75.77 & 39.50 & 46.70 \\
\hline Banking Crisis (assumed) & 1 & 1 & 1 & 1 & 1 & 1 & 1 & 1 & 1 \\
\hline Currency crisis (assumed) & 1 & 1 & 1 & 1 & 1 & 1 & 1 & 1 & 1 \\
\hline Predicted probability of a debt crisis & $<0$ & $<0$ & $<0$ & $<0$ & $<0$ & $<0$ & $<0$ & $<0$ & $<0$ \\
\hline Predicted probability of a currency crisis & 0.008 & 0.008 & 0.01 & 0.03 & 0.04 & 0.04 & 0.04 & 0.07 & 0.09 \\
\hline Average growth rate GDP per capita $2003-2008$ & 4.75 & 5.44 & 4.54 & 6.37 & 6.56 & 8.29 & 3.97 & 7.99 & 9.27 \\
\hline Expected growth loss $=$ probability of DEBT crisis $x-1.37$ & 0.00 & 0.00 & 0.00 & 0.00 & 0.00 & 0.00 & 0.00 & 0.00 & 0.00 \\
\hline $\begin{array}{l}\text { Expected growth loss = probability of CURRENCY crisis } x-1.37 \\
\quad \text { (percentage points) }\end{array}$ & -0.01 & -0.01 & -0.01 & -0.04 & -0.05 & -0.05 & -0.05 & -0.10 & -0.12 \\
\hline $\begin{array}{l}\text { Expected percentage drop in growth rate due to currency crisis } \\
\text { (Growth loss/Average Growth) }\end{array}$ & -0.23 & -0.20 & -0.30 & -0.65 & -0.84 & -0.66 & -1.38 & -1.20 & -1.33 \\
\hline
\end{tabular}

Notes: See the data appendix for sources and definitions of variables. Predicted probabilities are based on probit models in columns 4 and 5 of Table 1.

Original sin is calculated as the percentage of total household loans denominated in foreign currency as of January 2008. Source: Fitch Ratings see "Emerging Europe's Current

Account Deficits: Mind the Gap!" (2008); Short term interest rates are the yields on 6 month US treasury bills as of March $20,2009$.

Data on the net international investment position (NIIP) come from sources listed in the appendix.

The ratios of reserves/money come from International Financial Statistics January 2009 International Monetary Fund.

Czech Republic: Notes: Reserves and M2 as of Oct. 2008; Slovakia:Reserves and M2 as of August 2008; Poland; Reserves and M2 as of September 2008

Romania reserves, M2,as of October 2008; Bulgaria reserves, M2, as of October 2008; Lithuania reserves, money as of October 2008

Hungary reserves, M2, exchange rate as of October 2008; Estonia reserves, M2, exchange rate as of October 2008; Latvia reerves, M2 exchange rates as of October 2008 